Full paper

\title{
Covalent combination of polyoxometalate and graphitic carbon nitride for light-driven hydrogen peroxide production
}

\author{
Shen Zhao ${ }^{\mathrm{a}}$, Xu Zhao ${ }^{\mathrm{a}, *}$, Hui Zhang ${ }^{\mathrm{b}}$, Jiang $\mathrm{Li}^{\mathrm{a}}$, Yongfa Zhu ${ }^{\mathrm{c}}$ \\ a Key Laboratory of Drinking Water Science and Technology, Research Center for Eco-Environmental Sciences, Chinese Academy of Sciences, Beijing \\ 100085, China \\ b State Key Laboratory of Environmental Chemistry and Ecotoxicology, Research Center for Eco-Environmental Sciences, Chinese Academy of Sciences, \\ Beijing 100085, China \\ c Department of Chemistry, Tsinghua University, Beijing 100084, China
}

\section{A R T I C L E I N F O}

\section{Keywords:}

Graphitic carbon nitride

Polyoxometalates

Covalent combination

Hydrogen peroxide production

\begin{abstract}
A B S T R A C T
The polyoxometalate $(\mathrm{POM})$ cluster of $\left[\mathrm{PW}_{11} \mathrm{O}_{39}\right]^{7-}\left(\mathrm{PW}_{11}\right)$ has been successfully covalent combined with the three dimensionally ordered macroporous graphitic carbon nitride $\left(3 \mathrm{DOM} g-\mathrm{C}_{3} \mathrm{~N}_{4}\right.$ ) through the organic linker strategy. The characterization such as solid-state NMR and XPS results confirm the organosilicon agent of (triethoxysilyl)-propyl isocyanate can act as the linker to covalent combine the $\mathrm{PW}_{11}$ cluster with $3 \mathrm{DOM}$ g- $\mathrm{C}_{3} \mathrm{~N}_{4}$. The hybrid catalyst of $3 \mathrm{DOM} g-\mathrm{C}_{3} \mathrm{~N}_{4}-\mathrm{PW}_{11}$ exhibits efficient catalytic performance $\left(2.4 \mu \mathrm{mol} \mathrm{h} \mathrm{h}^{-1}\right)$ for lightdriven $\mathrm{H}_{2} \mathrm{O}_{2}$ production from $\mathrm{H}_{2} \mathrm{O}$ and $\mathrm{O}_{2}$ in the absence of organic electron donors. The ESR results suggest that one-electron reduction of $\mathrm{O}_{2}$ to $\bullet \mathrm{OOH}$ is indeed suppressed over $3 \mathrm{DOM} g-\mathrm{C}_{3} \mathrm{~N}_{4}-\mathrm{PW}_{11}$. Furthermore, the Koutecky-Levich plot obtained from electrochemical rotating disk electrode (RDE) analysis of oxygen reduction reaction (ORR) for $3 \mathrm{DOM} g-\mathrm{C}_{3} \mathrm{~N}_{4}-\mathrm{PW}_{11}$ reveals the value of electron transfer during the ORR process is 2.30, indicating the covalent combination can promote the two-electron $\mathrm{O}_{2}$ reduction. In addition, the recycle experiment results reveal that the heterogeneous $3 \mathrm{DOM} g-\mathrm{C}_{3} \mathrm{~N}_{4}-\mathrm{PW}_{11}$ is catalytic stable.
\end{abstract}

\section{Introduction}

Hydrogen peroxide $\left(\mathrm{H}_{2} \mathrm{O}_{2}\right)$ can act as both oxidant and reductant and be widely used in biological process, environmental remediation and chemical industry [1]. As one potential solar fuel, $\mathrm{H}_{2} \mathrm{O}_{2}$ has several advantages: 1) it is a clean reagent emitting only water as byproduct [2]; 2) it is superior to hydrogen $\left(\mathrm{H}_{2}\right)$ or other fuel gasses due to its convenient and safe storage and transportation in liquid formvvvvv [3]; and 3) it can be used as a single-compartment direct peroxide-peroxide fuel cell (DPPFC) that is structurally simpler and scales better than the two-compartment $\mathrm{H}_{2}$ based fuel cells [4]. However, two problems exist in the current $\mathrm{H}_{2} \mathrm{O}_{2}$ production: 1) the anthraquinone method used in industry catalyzed by Pd-based catalysts requires the regeneration of anthrahydroquinone by $\mathrm{H}_{2}$ [5a]; and 2) the direct synthesis of $\mathrm{H}_{2} \mathrm{O}_{2}$ with $\mathrm{H}_{2}$ and $\mathrm{O}_{2}$ catalyzed by $\mathrm{Pd}$ or Au-Pd catalysts should pay more attention to the potentially explosive nature of $\mathrm{H}_{2} / \mathrm{O}_{2}$ mixed gases [5b]. A noble metal-free approach capable of producing $\mathrm{H}_{2} \mathrm{O}_{2}$ without $\mathrm{H}_{2}$ is therefore desired.

$\mathrm{H}_{2} \mathrm{O}+1 / 2 \mathrm{O}_{2} \rightarrow \mathrm{H}_{2} \mathrm{O}_{2}\left(\Delta \mathrm{G}^{\mathrm{o}}=117 \mathrm{~kJ} \mathrm{~mol}^{-1}\right)$
$\mathrm{H}_{2} \mathrm{O}+2 \mathrm{~h}^{+} \rightarrow 1 / 2 \mathrm{O}_{2}+2 \mathrm{H}^{+}(1 \cdot 23 \mathrm{~V}$ vs. NHE $)$

$\mathrm{O}_{2}+2 \mathrm{H}^{+}+2 \mathrm{e}^{-} \rightarrow \mathrm{H}_{2} \mathrm{O}_{2}(0 \cdot 68 \mathrm{~V}$ vs. NHE)

Photocatalytic production of $\mathrm{H}_{2} \mathrm{O}_{2}$ from $\mathrm{H}_{2} \mathrm{O}$ and $\mathrm{O}_{2}$ by semiconductor photocatalysts can meet the above requirement (Eq. (1)) [6]. The solar-to- $\mathrm{H}_{2} \mathrm{O}_{2}$ conversion can be divided into two half reactions: 1) the photogenerated valence band holes $\left(\mathrm{VB} \mathrm{h}^{+}\right)$oxidizes $\mathrm{H}_{2} \mathrm{O}$ and produces $\mathrm{O}_{2}$ and $\mathrm{H}^{+}$(Eq. (2)); and 2) two-electron reduction of $\mathrm{O}_{2}$ by the conduction band electrons ( $\mathrm{CB} \mathrm{e} \mathrm{e}^{-}$) produces $\mathrm{H}_{2} \mathrm{O}_{2}$ (Eq. (3)). Among these semiconductor catalysts, graphitic carbon nitride $\left(\mathrm{g}-\mathrm{C}_{3} \mathrm{~N}_{4}\right)$-based catalysts exhibit good efficiency for light-driven $\mathrm{H}_{2} \mathrm{O}_{2}$ production [6b,e]. However, two problems hinder the improvement of the efficiency for $\mathrm{g}-\mathrm{C}_{3} \mathrm{~N}_{4}$-based photocatalysts: 1 ) the fast charge recombination caused intrinsically by the $\pi-\pi$ conjugated electronic system of $\mathrm{g}$ $\mathrm{C}_{3} \mathrm{~N}_{4}$ framework [7]; 2) the limited inhibition of the one-electron reduction of $\mathrm{O}_{2}$ (Eq. (4)) [8]. Therefore, introducing the guest molecules to $\mathrm{g}-\mathrm{C}_{3} \mathrm{~N}_{4}$ host is an effective option to promote the charge separation and the selectivity of the two-electron reduction of $\mathrm{O}_{2}$ to $\mathrm{H}_{2} \mathrm{O}_{2}$ [9].

$\mathrm{O}_{2}+\mathrm{H}^{+}+\mathrm{e}^{-} \rightarrow \cdot \mathrm{OOH}(-0 \cdot 13 \mathrm{~V}$ vs. NHE)

\footnotetext{
* Corresponding author.

E-mail address: zhaoxu@rcees.ac.cn (X. Zhao).
} 
$\mathrm{O}_{2}+4 \mathrm{H}^{+}+4 \mathrm{e}^{-} \rightarrow \mathrm{H}_{2} \mathrm{O}(1 \cdot 23 \mathrm{~V}$ vs. NHE $)$

As a class of discrete anionic metal oxides, polyoxometalates (POMs) have been extensively used as photocatalysts for water oxidation [10a], hydrogen evolution [10b], carbon dioxides $\left(\mathrm{CO}_{2}\right)$ reduction [10c], and selective organic synthesis [10d]. The reason for high performance of the above photocatalytic reactions is that: 1) POMs have strong light absorption with high molecular absorption coefficients $\left(\varepsilon>1 \times 10^{4} \mathrm{M}^{-1} \mathrm{~L}^{-1}\right)$ because of the presence of $\mathrm{O} \rightarrow \mathrm{M}$ ligand-tometal charge transfer (LMCT) bands; 2) POMs are highly redox-active and can undergo light-induced multi-electron redox-processes due to the high number of metal centres present; and 3) the structural integrity of the cluster shell is maintained during the photoredox processes indicating POMs are catalytic stable [11]. These advantages make POMs the ideal guest molecules for $\mathrm{g}-\mathrm{C}_{3} \mathrm{~N}_{4}$ host. Although POMs have been combined with g- $\mathrm{C}_{3} \mathrm{~N}_{4}$ [12], these hybrid materials based on the weak interaction such as electrostatic interaction and metal-ligand coordination suffer from stability issues owning to POMs leaching [13]. Therefore, the development of covalent combining POMs with g- $\mathrm{C}_{3} \mathrm{~N}_{4}$ to enhance the interaction between them is highly desirable.

Herein, we have covalent combined the POM cluster of $\left[\mathrm{PW}_{11} \mathrm{O}_{39}\right]^{7-}$ $\left(\mathrm{PW}_{11}\right)$ with $\mathrm{g}-\mathrm{C}_{3} \mathrm{~N}_{4}$ by taking the organic linker strategy [14]. The primary amine $\left(-\mathrm{NH}_{2}\right)$ groups of $\mathrm{g}-\mathrm{C}_{3} \mathrm{~N}_{4}$ frameworks can participate in organic reactions to introduce the functional groups to $\mathrm{g}-\mathrm{C}_{3} \mathrm{~N}_{4}$ frameworks [15]. However, the amounts of $-\mathrm{NH}_{2}$ groups on the lamellar g$\mathrm{C}_{3} \mathrm{~N}_{4}$ are quite small and the $\pi-\pi$ conjugated electronic system of g$\mathrm{C}_{3} \mathrm{~N}_{4}$ decreases the reactivity of $-\mathrm{NH}_{2}$ groups, which makes the reaction between the lamellar $\mathrm{g}-\mathrm{C}_{3} \mathrm{~N}_{4}$ and the organic linker difficult under mild conditions [16]. To overcome the above obstacles, three dimensionally ordered macroporous (3DOM) $\mathrm{g}-\mathrm{C}_{3} \mathrm{~N}_{4}$ with interconnected macroporous architecture and large amounts of $-\mathrm{NH}_{2}$ groups have been prepared by the thermal condensation-assisted colloidal crystal template method [17]. Therefore, the organosilicon agent of (triethoxysilyl)-propyl isocyanate can act as the linker to covalent combine the $\mathrm{PW}_{11}$ cluster with $3 \mathrm{DOM}$ g- $\mathrm{C}_{3} \mathrm{~N}_{4}$. The hybrid catalyst of $3 \mathrm{DOM}$ g- $\mathrm{C}_{3} \mathrm{~N}_{4}-\mathrm{PW}_{11}$ with well-defined and stable structure exhibits promoted charge separation and high selectivity of the two-electron reduction of $\mathrm{O}_{2}$ to $\mathrm{H}_{2} \mathrm{O}_{2}$ for light-driven $\mathrm{H}_{2} \mathrm{O}_{2}$ production from $\mathrm{H}_{2} \mathrm{O}$ and $\mathrm{O}_{2}$ in the absence of organic electron donors.

\section{Experimental section}

\subsection{Chemicals}

Tetraethyl orthosilicate (TEOS), cyanamide, (triethoxysilyl)-propyl isocyanate, triethylamine, ammonium hydroxide solution $\left(\mathrm{NH}_{3} \cdot \mathrm{H}_{2} \mathrm{O}\right.$, 28 wt\%), hydrochloric acid ( $\mathrm{HCl}, 37 \mathrm{wt} \%)$ and hydrofluoric acid (HF, $40 \mathrm{wt} \%$ ) were purchased from Alfa Asear company and used as received without further purification. 5,5-dimethyl-1-pyrroline (DMPO) were purchased from Sigma-Aldrich company. All solvents used were of analytical grade and were purchased from Fisher. Closepacked silica nanospheres [18] and $\mathrm{K}_{7}\left[\mathrm{PW}_{11} \mathrm{O}_{39}\right] \cdot 13 \mathrm{H}_{2} \mathrm{O}\left(\mathrm{K}-\mathrm{PW}_{11}\right)$ [19a] were synthesized and characterized in accordance with the literature.

\subsection{Preparation of $3 D O M g-C_{3} N_{4}[17,20]$}

The powders of close-packed silica nanospheres $(10.00 \mathrm{~g})$ and cyanamide $(4.50 \mathrm{~g})$ were heated to $60^{\circ} \mathrm{C}$ for $30 \mathrm{~min}$ to allow filling of the interparticle voids of close-packed silica nanospheres with molten cyanamide. The mixture of close-packed silica nanospheres and cyanamide was cooled to room temperature. After grinding, the mixture was put in a crucible with a lid and heated to $550{ }^{\circ} \mathrm{C}$ for $4 \mathrm{~h}$ in air. To remove the silica template, the mixture was soaked in $250 \mathrm{ml}$ of $10 \mathrm{wt} \% \mathrm{HF}$ aqueous solution for 1 day without stirring and the resulting solids were then recovered by centrifugation and washed with water. Pale-yellow powders of 3DOM g- $\mathrm{C}_{3} \mathrm{~N}_{4}$ were finally obtained by drying at $60^{\circ} \mathrm{C}$ in air. Based on the TGA and EA analysis, the formula of 3DOM g- $\mathrm{C}_{3} \mathrm{~N}_{4}$ was determined to be $\mathrm{C}_{2.44} \mathrm{~N}_{4} \mathrm{H}_{1.57}$. The lamellar g$\mathrm{C}_{3} \mathrm{~N}_{4}$ have been prepared without templates for comparison.

\subsection{Preparation of $3 D O M g-C_{3} N_{4}-P W_{11}$}

$3 \mathrm{DOM} \mathrm{g}-\mathrm{C}_{3} \mathrm{~N}_{4}(1.00 \mathrm{~g})$ was dispersed in $50 \mathrm{ml}$ acetonitrile and (triethoxysilyl)-propyl isocyanate $(1.00 \mathrm{~g}, 4.04 \mathrm{mmol})$ was added. The reaction mixture was kept at $80{ }^{\circ} \mathrm{C}$, to which were added small amounts of triethylamine. After reaction for $24 \mathrm{~h}$, the $3 \mathrm{DOM}$ g- $\mathrm{C}_{3} \mathrm{~N}_{4}$ linker was obtained by centrifugation and used directly in the next step after washing with ethanol. Then, $\mathrm{K}_{-} \mathrm{PW}_{11}(6.40 \mathrm{~g}, 2.02 \mathrm{mmol})$ was added to the $300 \mathrm{ml}$ aqueous dispersion of $3 \mathrm{DOM} \mathrm{g}-\mathrm{C}_{3} \mathrm{~N}_{4}$ linker. After adjusting the $\mathrm{pH}$ to 0.5 with $1 \mathrm{M} \mathrm{HCl}$, the reaction mixture was stirred for $24 \mathrm{~h}$. The hybrid catalyst of $3 \mathrm{DOM} \mathrm{g}-\mathrm{C}_{3} \mathrm{~N}_{4}-\mathrm{PW}_{11}$ was centrifugated, washed by water, and then dried at $60{ }^{\circ} \mathrm{C}$ in air. Based on the TGA, EA and ICP analysis, the formula of $3 \mathrm{DOM} \mathrm{g-C} \mathrm{C}_{3}-\mathrm{PW}_{11}$ was determined to be $\mathrm{C}_{2.44} \mathrm{~N}_{4} \mathrm{H}_{1.53}\left(\mathrm{~K}_{3} \mathrm{PW}_{11} \mathrm{O}_{42} \mathrm{Si}_{2} \mathrm{C}_{8} \mathrm{H}_{14} \mathrm{~N}_{2}\right)_{0.021}\left(40.41\right.$ wt\% $\left.\mathrm{PW}_{11}\right)$. For comparison, 3DOM g- $\mathrm{C}_{3} \mathrm{~N}_{4}-\mathrm{PW}_{11}$-IMP based on the electrostatic interaction has been prepared through the impregnation method with the same $\mathrm{PW}_{11}$ weight percentage as $3 \mathrm{DOM} \mathrm{g}_{\mathrm{C}} \mathrm{C}_{4}-\mathrm{PW}_{11}$ based on covalent interaction.

\subsection{Photocatalytic evaluation}

The photocatalytic activities were evaluated by the activation of oxygen under light irradiation $(\lambda>320 \mathrm{~nm})$ [6a]. A $300 \mathrm{~W}$ Xenon lamp (Perfect Light company, Beijing) was chosen as light source. During each photocatalytic performance, $0.10 \mathrm{~g}$ of catalyst was dispersed into $100 \mathrm{ml}$ of distilled water in a container $\left(1 \mathrm{~g} \mathrm{~L}^{-1}\right.$ catalyst). After that, the dispersion was stirred in the dark for $60 \mathrm{~min}$ to ensure the adsorptiondesorption equilibrium among the catalyst, dissolved oxygen and water before light irradiation. During the irradiation, $1.5 \mathrm{ml}$ of the suspensions was taken from the reaction cell at given time intervals, and then filtrated to remove the catalysts. The concentrations of $\mathrm{H}_{2} \mathrm{O}_{2}$ generated were determined by iodometric titration [21]. After completion of the reaction, the catalysts can be recovered by centrifugation, washed with water, and dried at $60^{\circ} \mathrm{C}$ in air. To investigate the decomposition behavior of $\mathrm{H}_{2} \mathrm{O}_{2}$ over the photocatalysts, a sample of $1 \mathrm{~g} \mathrm{~L}^{-1}$ was dispersed in $\mathrm{H}_{2} \mathrm{O}_{2}$ solution (initial concentration: $1 \mathrm{mM}$ ) and irradiated for $60 \mathrm{~min}$ under continuous stirring.

\subsection{Rotating disk electrode (RDE) measurements}

The measurements were performed on a Pine AFMSRXE 1523 advanced electrochemical system with a three-electrode cell using an $\mathrm{Ag} / \mathrm{AgCl}$ electrode and a Pt wire electrode as the reference and counter electrode, respectively [6e]. The working electrode was prepared as follows: catalysts $(50 \mathrm{mg})$ were dispersed in $\mathrm{EtOH}(2 \mathrm{ml})$ containing Nafion $(50 \mathrm{mg})$ by ultrasonication. The slurry $(20 \mu \mathrm{l})$ was put onto a Pt disk electrode and dried at room temperature. The linear sweep voltammogram (LSV) were obtained in an $\mathrm{O}_{2}$-saturated $0.1 \mathrm{M}$ phosphate buffer solution ( $\mathrm{pH}$ 7) with a scan rate $10 \mathrm{mV} \mathrm{s}^{-1}$ after $\mathrm{O}_{2}$ bubbling for $5 \mathrm{~min}$.

\section{6. $\cdot \mathrm{OOH}$ radical examination}

- $\mathrm{OOH}$ was examined by a Bruker model electron spin resonance (ESR) A300-10/12 spectrometer equipped with a quanta-Ray Nd: YAG laser system employing 5,5-dimethyl-l-pyrroline-N-oxide (DMPO) as the spin trapper. Catalyst $(0.10 \mathrm{~g})$ was added to a methanol/water mixture $(9 / 1 \mathrm{v} / \mathrm{v}, 100 \mathrm{ml})$ containing DMPO $(0.125 \mathrm{mmol})$ within a container. After $\mathrm{O}_{2}$ bubbling for $10 \mathrm{~min}$, the container was photo irradiated for $3 \mathrm{~min}$. The catalyst was recovered by filtration, and the solution was subjected to analysis at room temperature. 
<smiles>CN(C)C1=NC2=NC(N)=NC3=NC(N(C)C)=NC(=N1)N23</smiles>

$3 \mathrm{DOM} \mathrm{g-C} \mathrm{N}_{4}$

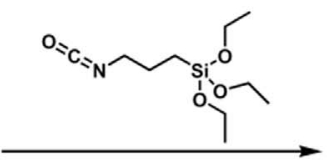<smiles>CCO[Si](CCCNC(=O)NC1=NC2=NC(N(C)C)=NC3=NC(N(C)C)=NC(=N1)N23)(OCC)OCC</smiles>

3DOM g- $\mathrm{C}_{3} \mathrm{~N}_{4}$ Linker
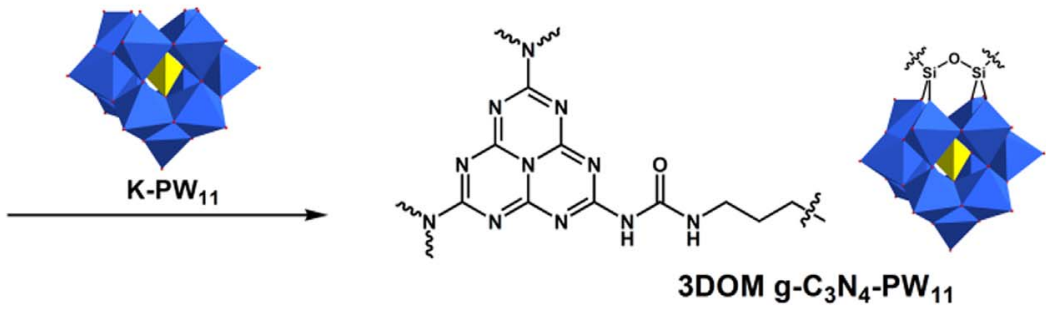

Fig. 1. Preparation process of $3 D O M g-\mathrm{C}_{3} \mathrm{~N}_{4}-\mathrm{PW}_{11}$.

\section{Results and discussion}

\subsection{Covalent combination of $P W_{11}$ and $3 D O M g-C_{3} N_{4}$}

The covalent combination of POM cluster of $\mathrm{PW}_{11}$ and 3DOM g$\mathrm{C}_{3} \mathrm{~N}_{4}$ has achieved by taking the organic linker strategy [14]. The $3 \mathrm{DOM}$ g- $\mathrm{C}_{3} \mathrm{~N}_{4}$ with interconnected macroporous architecture and larger amounts of $-\mathrm{NH}_{2}$ groups than those of lamellar $\mathrm{g}-\mathrm{C}_{3} \mathrm{~N}_{4}$ (Fig. $\mathrm{S} 1$ ) have been prepared by the thermal condensation-assisted colloidal crystal template method [17]. As shown in Fig. 1, the organosilicon linkers can be grafted onto $3 \mathrm{DOM}$ g- $\mathrm{C}_{3} \mathrm{~N}_{4}$ through the formation of carbamido groups to generate the $3 \mathrm{DOM} g-\mathrm{C}_{3} \mathrm{~N}_{4}$ linker. The POM cluster of $\mathrm{PW}_{11}$ can covalent connect with $3 \mathrm{DOM}$ g- $\mathrm{C}_{3} \mathrm{~N}_{4}$ linker under acidic solution following the reported method [19]. In this way, the POM cluster of $\mathrm{PW}_{11}$ has been covalent combined with $3 \mathrm{DOM}$ g- $\mathrm{C}_{3} \mathrm{~N}_{4}$ to form the hybrid catalyst of $3 \mathrm{DOM}$ g- $\mathrm{C}_{3} \mathrm{~N}_{4}-\mathrm{PW}_{11}$ for light-driven $\mathrm{H}_{2} \mathrm{O}_{2}$ production from $\mathrm{H}_{2} \mathrm{O}$ and $\mathrm{O}_{2}$.

\subsection{Characterization of $3 D O M g-C_{3} N_{4}-P W_{11}$}

The covalent combination of $\mathrm{PW}_{11}$ and $3 \mathrm{DOM}$ g- $\mathrm{C}_{3} \mathrm{~N}_{4}$ has been firstly confirmed by solid-state NMR. The ${ }^{13} \mathrm{C}$ MAS NMR spectrum of $3 \mathrm{DOM} \mathrm{g}-\mathrm{C}_{3} \mathrm{~N}_{4}$ (Fig. 2A) exhibits two typical signal groups of the g$\mathrm{C}_{3} \mathrm{~N}_{4}$ : the first signal groups at 163.0 and $165.1 \mathrm{ppm}$ with a $1.9: 1$ intensity ratio are the resonances for the $\mathrm{CN}_{2}\left(\mathrm{NH}_{2}\right)$ groups, and the second signal groups at $156.8 \mathrm{ppm}$ belong to the $\mathrm{CN}_{3}$ groups of the cyameluric nucleus [22]. In contrast, the ${ }^{13} \mathrm{C}$ MAS NMR spectrum of $3 \mathrm{DOM} \mathrm{g}-\mathrm{C}_{3} \mathrm{~N}_{4}-\mathrm{PW}_{11}$ (Fig. 2A) shows not only the two typical signal groups of $3 \mathrm{DOM} \mathrm{g}-\mathrm{C}_{3} \mathrm{~N}_{4}$ but also the signal groups at $9.8 \mathrm{ppm}$ assigned to the organosilicon linker. The presence of the signal at $9.8 \mathrm{ppm}$ confirms the organosilicon linker has been covalent linked with 3DOM g- $\mathrm{C}_{3} \mathrm{~N}_{4}$. The ${ }^{29} \mathrm{Si}$ MAS NMR spectrum of $3 \mathrm{DOM}$ g- $\mathrm{C}_{3} \mathrm{~N}_{4}-\mathrm{PW}_{11}$ (Fig. 2B) displays resonance peaks centered at $-64.9 \mathrm{ppm}$, which corresponds to $\mathrm{RSi}(\mathrm{OM})_{3}\left(\mathrm{~T}^{3}\right.$ mode, $\mathrm{R}=\mathrm{CH}_{2} \mathrm{CH}_{2} \mathrm{CH}_{2} \mathrm{NH}\left(\mathrm{C}^{=} \mathrm{O}\right)-, \mathrm{M}=\mathrm{Si}$ or $\left.\mathrm{W}\right)$ [19a]. The presence of the $\mathrm{T}^{3}$ signal reveals that three $\mathrm{M}-\mathrm{O}-\mathrm{Si}(\mathrm{M}=\mathrm{Si}$ or $\mathrm{W})$ bonds around the $\mathrm{Si}$ atom, which confirms that the organosilicon linker are covalently tethered onto the vacancy of $\mathrm{PW}_{11}$ cluster [19b]. The above ${ }^{13} \mathrm{C}$ and ${ }^{29} \mathrm{Si}$ MAS NMR results confirm that the $\mathrm{PW}_{11}$ cluster has been successfully covalent combined with $3 \mathrm{DOM} \mathrm{g}-\mathrm{C}_{3} \mathrm{~N}_{4}$ by the organosilicon linker. The similar signals at around -13.7 and $-13.4 \mathrm{ppm}$ of the ${ }^{31} \mathrm{P}$ MAS NMR for K-PW 11 and 3DOM g- $\mathrm{C}_{3} \mathrm{~N}_{4}-\mathrm{PW}_{11}$ (Fig. 2C) reveal that the primary structure of $\mathrm{PW}_{11}$ cluster has been well preserved after covalent combination [13]. More characterization should be performed to investigate the structure and composition of 3DOM g- $\mathrm{C}_{3} \mathrm{~N}_{4}-\mathrm{PW}_{11}$.

The XRD pattern of $3 \mathrm{DOM}$ g- $\mathrm{C}_{3} \mathrm{~N}_{4}, \mathrm{~K}-\mathrm{PW}_{11}$ and $3 \mathrm{DOM} \mathrm{g}-\mathrm{C}_{3} \mathrm{~N}_{4^{-}}$ $\mathrm{PW}_{11}$ is shown in Fig. S2. The diffraction peaks located at $12.9^{\circ}$ and $27.4^{\circ}$ of $3 \mathrm{DOM}$ g- $\mathrm{C}_{3} \mathrm{~N}_{4}$ are assigned to the g- $\mathrm{C}_{3} \mathrm{~N}_{4}$ with (100) and (002) lines, which come from in-plane repeating tri-s-triazine and stacking of the conjugated aromatic units, respectively [23]. For 3DOM g- $\mathrm{C}_{3} \mathrm{~N}_{4}$ $\mathrm{PW}_{11}$, the weak intensity of characteristic peaks at $27.4^{\circ}$ and the presence of typical $\mathrm{PW}_{11^{-}}$-related peaks in the range of $8-11^{\circ}$ indicates that the $\mathrm{PW}_{11}$ cluster has been successfully covalent combined with 3 DOM g $-\mathrm{C}_{3} \mathrm{~N}_{4}$ through the organosilicon linker [12a,b,d]. Fig. S3 shows the IR spectrum of $3 \mathrm{DOM} \mathrm{g}_{-} \mathrm{C}_{3} \mathrm{~N}_{4}, \mathrm{~K}-\mathrm{PW}_{11}$ and $3 \mathrm{DOM} \mathrm{g}$ $\mathrm{C}_{3} \mathrm{~N}_{4}-\mathrm{PW}_{11}$. The peaks in the range of $1180-1755 \mathrm{~cm}^{-1}$ have been observed in both $3 \mathrm{DOM} g-\mathrm{C}_{3} \mathrm{~N}_{4}$ and $3 \mathrm{DOM}$ g- $\mathrm{C}_{3} \mathrm{~N}_{4}-\mathrm{PW}_{11}$, which are the typical vibrations of hepatizine-based molecular units [12c]. The vibrations at 1067,983 , and $892 \mathrm{~cm}^{-1}$ corresponding to chemical bonds of $\mathrm{W}^{=} \mathrm{O}, \mathrm{P}-\mathrm{O}$, and $\mathrm{W}-\mathrm{O}-\mathrm{W}$ in the Keggin POM of $\mathrm{PW}_{11}$ can be found in both $\mathrm{K}-\mathrm{PW} \mathrm{W}_{11}$ and $3 \mathrm{DOM}$ g- $\mathrm{C}_{3} \mathrm{~N}_{4}-\mathrm{PW}_{11}$ [24]. The above IR results indicates that the primary structure of $3 \mathrm{DOM} \mathrm{g-} \mathrm{C}_{3} \mathrm{~N}_{4}$ and $\mathrm{PW}_{11}$ cluster has been well preserved after covalent combination. In addition, the broad peaks at around $3100-3400 \mathrm{~cm}^{-1}$ are mainly due to the $-\mathrm{NH}_{2}$ groups of the adsorbed $\mathrm{H}_{2} \mathrm{O}$ from air, which become weaker after
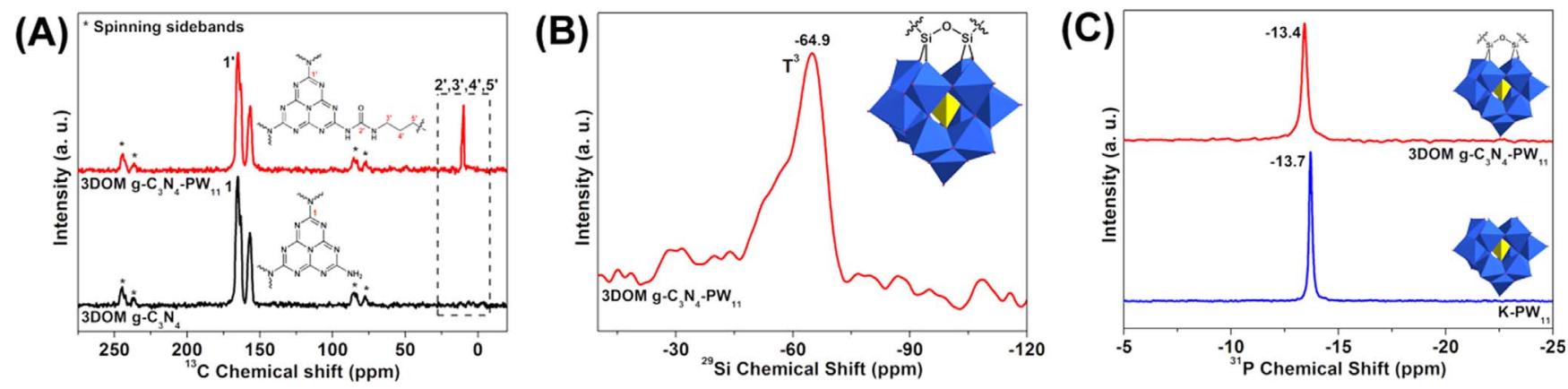

Fig. 2. ${ }^{13} \mathrm{C}(\mathrm{A}),{ }^{29} \mathrm{Si}(\mathrm{B})$ and ${ }^{31} \mathrm{P}(\mathrm{C}) \mathrm{MAS}$ NMR spectra of $3 \mathrm{DOM}$ g- $\mathrm{C}_{3} \mathrm{~N}_{4}, \mathrm{~K}-\mathrm{PW}_{11}$ and $3 \mathrm{DOM}$ g- $\mathrm{C}_{3} \mathrm{~N}_{4}-\mathrm{PW}_{11}$. 
covalent combination [15], indicating the decreased content of surface $-\mathrm{NH}_{2}$ groups in $3 \mathrm{DOM} \mathrm{g}-\mathrm{C}_{3} \mathrm{~N}_{4}-\mathrm{PW}_{11} \cdot \mathrm{CO}_{2}$ temperature programmed desorption $\left(\mathrm{CO}_{2}\right.$-TPD) has been performed to investigate the content of $-\mathrm{NH}_{2}$ groups in $3 \mathrm{DOM}$ g- $\mathrm{C}_{3} \mathrm{~N}_{4}$ and $3 \mathrm{DOM}$ g- $\mathrm{C}_{3} \mathrm{~N}_{4}-\mathrm{PW}_{11}$ as the $-\mathrm{NH}_{2}$ groups can act as Lewis base sites and adsorb slightly acidic $\mathrm{CO}_{2}$ molecules [25]. Fig. S4 shows the peak area of $3 \mathrm{DOM}$ g- $\mathrm{C}_{3} \mathrm{~N}_{4}-\mathrm{PW}_{11}$ is much smaller than that of $3 \mathrm{DOM} g-\mathrm{C}_{3} \mathrm{~N}_{4}$. Furthermore, the zeta potentials of aqueous suspension of $3 \mathrm{DOM} \mathrm{g}_{-} \mathrm{C}_{3} \mathrm{~N}_{4}$ and $3 \mathrm{DOM} \mathrm{g}-$ $\mathrm{C}_{3} \mathrm{~N}_{4}-\mathrm{PW}_{11}$ has been measured because the $-\mathrm{NH}_{2}$ groups with the free lone pair electrons on nitrogen atoms can act as proton acceptors and acquire positive surface charges [26]. Fig. S5 shows the zeta potential of $3 \mathrm{DOM} \mathrm{g}-\mathrm{C}_{3} \mathrm{~N}_{4}-\mathrm{PW}_{11}(-33.9 \mathrm{mV})$ is more negative than that of 3 DOM g- $\mathrm{C}_{3} \mathrm{~N}_{4}(-14.7 \mathrm{mV})$. The above IR, $\mathrm{CO}_{2}$-TPD and zeta potential results reveal the significant decrease of $-\mathrm{NH}_{2}$ groups in $3 \mathrm{DOM} g-\mathrm{C}_{3} \mathrm{~N}_{4}$ after covalent combination, confirming the reaction between the $-\mathrm{NH}_{2}$ groups of $3 \mathrm{DOM} \mathrm{g}-\mathrm{C}_{3} \mathrm{~N}_{4}$ and the organosilicon linkers. The isotherms for 3DOM g- $\mathrm{C}_{3} \mathrm{~N}_{4}$ and $3 \mathrm{DOM}$ g- $\mathrm{C}_{3} \mathrm{~N}_{4}-\mathrm{PW}_{11}$ (Fig. S6A) are consistent with type II isotherm with a type $\mathrm{H} 3$ hysteresis loop in the relative pressure $\left(\mathrm{P} / \mathrm{P}_{0}\right)$ range of $0.6-1.0$ according to IUPAC classification. These two catalysts present a broad pore-size distribution curve (2$132 \mathrm{~nm}$ ) from mesopore range to macropore range (Fig. S6B). The above results confirm both $3 \mathrm{DOM}$ g- $\mathrm{C}_{3} \mathrm{~N}_{4}$ and $3 \mathrm{DOM}$ g- $\mathrm{C}_{3} \mathrm{~N}_{4}-\mathrm{PW}_{11}$ possess clear macroporous structure [27]. The surface area, pore volume and pore diameter of $3 \mathrm{DOM} g-\mathrm{C}_{3} \mathrm{~N}_{4}$ and $3 \mathrm{DOM}$ g- $\mathrm{C}_{3} \mathrm{~N}_{4}-\mathrm{PW}_{11}$ are shown in Table S1. Compared with $3 \mathrm{DOM} \mathrm{g-} \mathrm{C}_{3} \mathrm{~N}_{4}$, the decrease in these values of $3 \mathrm{DOM} \mathrm{g}-\mathrm{C}_{3} \mathrm{~N}_{4}-\mathrm{PW}_{11}$ is due to the covalent combination of $\mathrm{PW}_{11}$ cluster and the macroporous structure of $3 \mathrm{DOM} g-\mathrm{C}_{3} \mathrm{~N}_{4}$ $[12 \mathrm{a}, \mathrm{d}, \mathrm{d}]$. Thermogravimetry analysis (TGA) curves for 3DOM g$\mathrm{C}_{3} \mathrm{~N}_{4}, \mathrm{~K}-\mathrm{PW}_{11}$ and $3 \mathrm{DOM}$ g- $\mathrm{C}_{3} \mathrm{~N}_{4}-\mathrm{PW}_{11}$ are shown in Fig. S7. The total weight loss of $3 \mathrm{DOM} \mathrm{g-} \mathrm{C}_{3} \mathrm{~N}_{4}$ is $93.67 \%$ between 50 and $800{ }^{\circ} \mathrm{C}$ due to the direct thermal decomposition of $3 \mathrm{DOM} \mathrm{g}-\mathrm{C}_{3} \mathrm{~N}_{4}$. For K-PW $\mathrm{PW}_{11}$, the weight loss in the range of $50-150{ }^{\circ} \mathrm{C}$ range $(2.14 \%)$ corresponds to the loss of physisorbed water and crystallization water and the weight loss in the range of $150-600{ }^{\circ} \mathrm{C}(2.78 \%)$ is assigned to the Keggin structure decomposition [24]. According to the above results, the actual weight percentage of $\mathrm{PW}_{11}$ cluster for $3 \mathrm{DOM} g-\mathrm{C}_{3} \mathrm{~N}_{4}$ is $40.41 \%$. Combining the TGA, EA and ICP analysis (Table S2), the molecular formulas of $3 \mathrm{DOM}$ g- $\mathrm{C}_{3} \mathrm{~N}_{4}$ and $3 \mathrm{DOM} \mathrm{g}-\mathrm{C}_{3} \mathrm{~N}_{4}-\mathrm{PW}_{11}$ can be given as $\mathrm{C}_{2.44} \mathrm{~N}_{4} \mathrm{H}_{1.57}$ and $\mathrm{C}_{2.44} \mathrm{~N}_{4} \mathrm{H}_{1.53}\left(\mathrm{~K}_{3} \mathrm{PW}_{11} \mathrm{O}_{42} \mathrm{Si}_{2} \mathrm{C}_{8} \mathrm{H}_{14} \mathrm{~N}_{2}\right)_{0.021}$.
As shown in Fig. 3A, XPS peaks of $\mathrm{C} 1 \mathrm{~s}$ for 3DOM g- $\mathrm{C}_{3} \mathrm{~N}_{4}$ and $3 \mathrm{DOM} \mathrm{g}-\mathrm{C}_{3} \mathrm{~N}_{4}-\mathrm{PW}_{11}$ can be fitted with two peaks at binding energies of around 284.2 and $287.6 \mathrm{eV}$, which are ascribed to the C-C groups and the tertiary carbon $\mathrm{C}-\mathrm{N}_{3}$, respectively [8b]. The area ratios of these two peaks are 0.26 and 2.41 for $3 \mathrm{DOM}$ g- $\mathrm{C}_{3} \mathrm{~N}_{4}$ and $3 \mathrm{DOM} g-\mathrm{C}_{3} \mathrm{~N}_{4}-\mathrm{PW}_{11}$. The tremendous increase of the $\mathrm{C}-\mathrm{C}$ groups supports the organosilicon linker has been covalent linked with $3 \mathrm{DOM}$ g- $\mathrm{C}_{3} \mathrm{~N}_{4}$. Nevertheless, the XPS peaks of $\mathrm{N} 1 \mathrm{~s}$ (Fig. 3B) for 3DOM g- $\mathrm{C}_{3} \mathrm{~N}_{4}$ can be fitted with three peaks at 398.0, 399.6, and $404.2 \mathrm{eV}$, which are assigned to the $\mathrm{N}-\left(\mathrm{C}_{2}\right)$, $\mathrm{N}-\left(\mathrm{C}_{3}\right)$,

and $-\mathrm{NH}_{2}$, respectively [8b]. However, the $3 \mathrm{DOM} g-\mathrm{C}_{3} \mathrm{~N}_{4}-\mathrm{PW}_{11}$ only exhibits two peaks at 398.4 and $399.7 \mathrm{eV}$ corresponding to $\mathrm{N}-\left(\mathrm{C}_{2}\right)$ and $\mathrm{N}-\left(\mathrm{C}_{3}\right)$. The disappearance of $-\mathrm{NH}_{2}$ peak indicates that the $-\mathrm{NH}_{2}$ groups of $3 \mathrm{DOM} \mathrm{g}-\mathrm{C}_{3} \mathrm{~N}_{4}$ react with NCO- groups of silane coupling agent to form the carbamido groups during the covalent combination of $\mathrm{PW}_{11}$ cluster with $3 \mathrm{DOM} \mathrm{g}-\mathrm{C}_{3} \mathrm{~N}_{4}$. The above $\mathrm{C} 1 \mathrm{~s}$ and $\mathrm{N} 1 \mathrm{~s}$ XPS results support the ${ }^{13} \mathrm{C}$ MAS NMR results of 3DOM g- $\mathrm{C}_{3} \mathrm{~N}_{4}$ and $3 \mathrm{DOM}$ g$\mathrm{C}_{3} \mathrm{~N}_{4}-\mathrm{PW}_{11}$. The XPS peak of Si 2p (Fig. 3C) for 3DOM g- $\mathrm{C}_{3} \mathrm{~N}_{4}-\mathrm{PW}_{11}$ shows one peak at $101.8 \mathrm{eV}$ corresponding to $\mathrm{R}-\mathrm{Si}-\left(\mathrm{O}_{3}\right) \quad(\mathrm{R}=$ $\left.\mathrm{CH}_{2} \mathrm{CH}_{2} \mathrm{CH}_{2} \mathrm{NH}\left(\mathrm{C}^{=} \mathrm{O}\right)-\right)$, which is in accordance with ${ }^{29} \mathrm{Si}$ MAS NMR result of $3 \mathrm{DOM} \mathrm{g}-\mathrm{C}_{3} \mathrm{~N}_{4}-\mathrm{PW}_{11}$ [28]. Both the 3DOM g- $\mathrm{C}_{3} \mathrm{~N}_{4}$ and 3DOM g- $\mathrm{C}_{3} \mathrm{~N}_{4}-\mathrm{PW}_{11}$ show one P 2p XPS peak at $133.3 \mathrm{eV}$ (Fig. 3D). In addition, XPS peaks of $\mathrm{W} 4 \mathrm{f}$ (Fig. $3 \mathrm{E}$ ) for $\mathrm{K}-\mathrm{PW}_{11}$ and $3 \mathrm{DOM} \mathrm{g-} \mathrm{C}_{3} \mathrm{~N}_{4}$ $\mathrm{PW}_{11}$ can be fitted with two peaks at binding energies of around 34.9 and $37.1 \mathrm{eV}$ (W $4 \mathrm{f}_{7 / 2}$ and $\mathrm{W} 4 \mathrm{f}_{5 / 2}$ ), which are consistent with a W(VI) oxidation state [13]. The P $2 \mathrm{p}$ and $\mathrm{W} 4 \mathrm{f}$ XPS results reveal that the primary structure of $\mathrm{PW}_{11}$ cluster has been well preserved after covalent combination. XPS peaks of $\mathrm{O} 1 \mathrm{~s}$ (Fig. $3 \mathrm{~F}$ ) for K-PW $\mathrm{PW}_{11}$ and $3 \mathrm{DOM} \mathrm{g}-\mathrm{C}_{3} \mathrm{~N}_{4}-\mathrm{PW}_{11}$ can be fitted with two peaks at binding energies of around 531.3 and $530.0 \mathrm{eV}$, which are ascribed to the W-O-O-W/Si and $\mathrm{W}^{=} \mathrm{O}$, respectively [12c]. The area ratios of these two peaks are 0.31 and 1.06 for $\mathrm{K}-\mathrm{PW}_{11}$ and $3 \mathrm{DOM} \mathrm{g}-\mathrm{C}_{3} \mathrm{~N}_{4}-\mathrm{PW}_{11}$.

The largely increase of the $\mathrm{W}-\mathrm{O}-\mathrm{O}-\mathrm{W} / \mathrm{Si}$ supports the organosilicon linker are covalently tethered onto the vacancy of $\mathrm{PW}_{11}$ cluster. The above XPS results confirm the $\mathrm{PW}_{11}$ cluster has been covalent combination with $3 \mathrm{DOM}$ g- $\mathrm{C}_{3} \mathrm{~N}_{4}$ through the organosilicon linker and the primary structure of $\mathrm{PW}_{11}$ cluster has been well preserved after covalent combination.

Fig. $\mathrm{S} 8$ are the TEM images of $3 \mathrm{DOM}$ g- $\mathrm{C}_{3} \mathrm{~N}_{4}$ (Fig. S8A-C) and

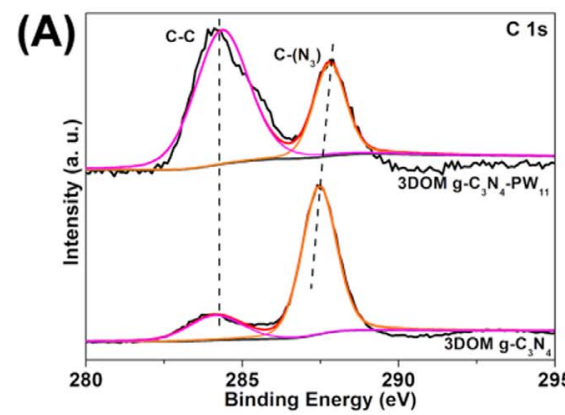

(B)
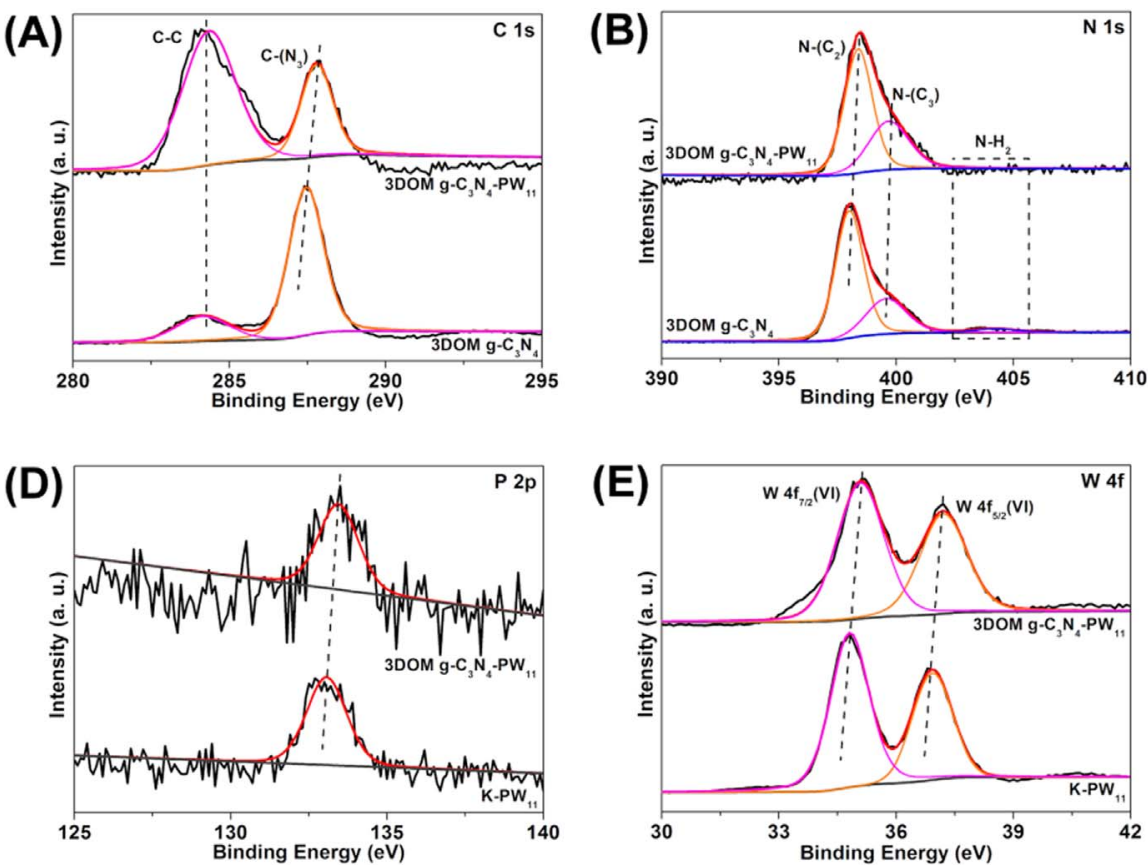

(E)

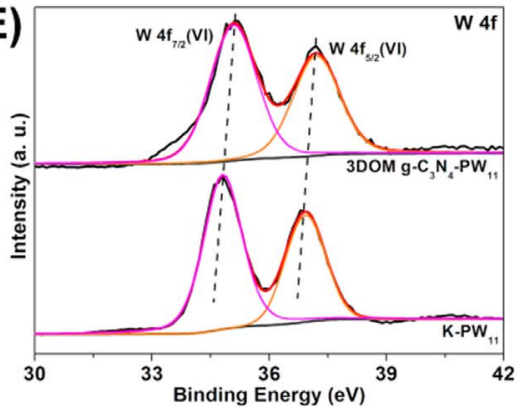

(C)

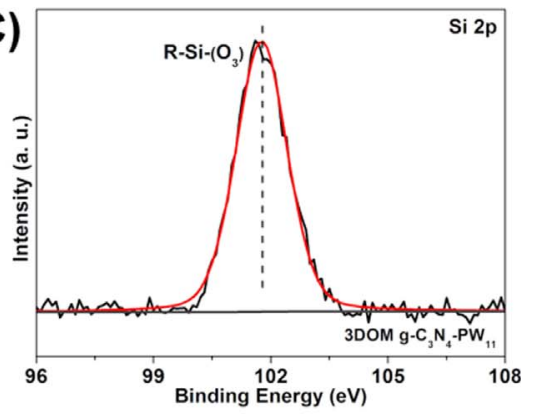

(F)

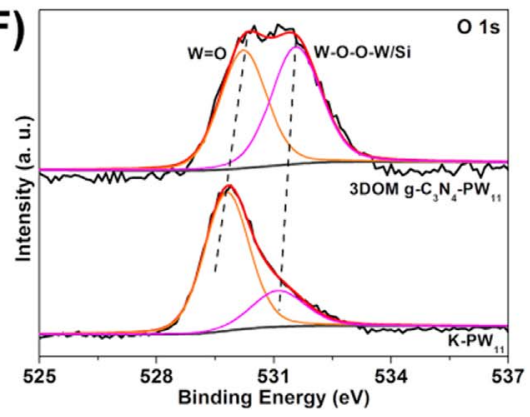

Fig. 3. C $1 \mathrm{~s}$ (A), N $1 \mathrm{~s}$ (B), Si 2p (C), P 2p (D), W 4 f (E), and O $1 \mathrm{~s}(\mathrm{~F}) \mathrm{XPS}$ spectra of $3 \mathrm{DOM}$ g- $\mathrm{C}_{3} \mathrm{~N}_{4}, \mathrm{~K}_{-} \mathrm{PW}_{11}$ and $3 \mathrm{DOM}$ g-C $3 \mathrm{~N}_{4}-\mathrm{PW}_{11}$. 


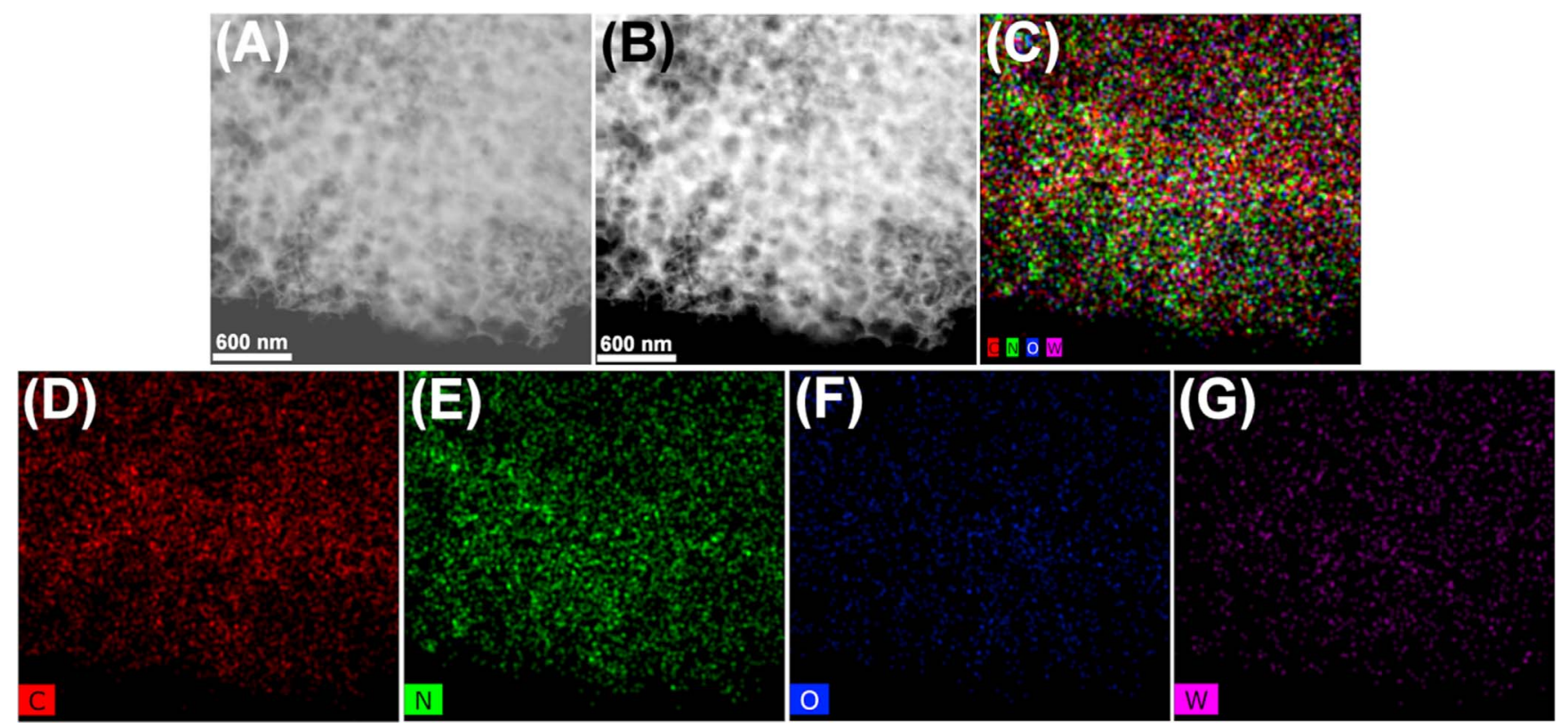

Fig. 4. STEM images (A and B) and corresponding elemental mappings (C-G) of 3DOM g- $\mathrm{C}_{3} \mathrm{~N}_{4}-\mathrm{PW}_{11}$.

3 DOM $\mathrm{g}^{-} \mathrm{C}_{3} \mathrm{~N}_{4}-\mathrm{PW}_{11}$ (Fig. S8D-F), which exhibit interconnected macroporous architecture with the average pore diameter of 260$350 \mathrm{~nm}$ [17]. However, $\mathrm{PW}_{11}$ clusters cannot be observed obviously in the HR-TEM images of 3DOM g- $\mathrm{C}_{3} \mathrm{~N}_{4}-\mathrm{PW}_{11}$ (Fig. S8D-F), mainly due to the $\mathrm{PW}_{11}$ clusters are highly dispersed on $3 \mathrm{DOM} \mathrm{g}-\mathrm{C}_{3} \mathrm{~N}_{4}$ [12a,b, d]. To investigate the dispersion of $\mathrm{PW}_{11}$ on $3 \mathrm{DOM} \mathrm{g}-\mathrm{C}_{3} \mathrm{~N}_{4}$, STEMMapping characterization has been performed. As shown in Fig. 4A, $3 \mathrm{DOM} \mathrm{g-} \mathrm{C}_{3} \mathrm{~N}_{4}-\mathrm{PW}_{11}$ remains the macroporous structure after covalent combination. The STEM image in Fig. 4B shows a rough defect-rich surface with curvatures, distortions, protuberances, and crumpled edges [12c]. The elemental mappings of $\mathrm{C}, \mathrm{N}, \mathrm{O}$, and $\mathrm{W}$ (Fig. 4C-G) clearly exhibit the $\mathrm{PW}_{11}$ clusters are highly dispersed on the surface of $3 \mathrm{DOM} \mathrm{g}-\mathrm{C}_{3} \mathrm{~N}_{4}$ after covalent combination.

The above characterization results confirm that the $\mathrm{PW}_{11}$ cluster has been covalent combined with $3 \mathrm{DOM}$ g- $\mathrm{C}_{3} \mathrm{~N}_{4}$ to form the hybrid catalyst of $3 \mathrm{DOM} \mathrm{g}-\mathrm{C}_{3} \mathrm{~N}_{4}-\mathrm{PW}_{11}$. Furthermore, the catalytic performance of 3DOM g- $\mathrm{C}_{3} \mathrm{~N}_{4}-\mathrm{PW}_{11}$ should be investigated.

\subsection{Catalytic performance of $3 \mathrm{DOM} g-C_{3} \mathrm{~N}_{4}-\mathrm{P} W_{11}$}

The light-driven $\mathrm{H}_{2} \mathrm{O}_{2}$ production over various catalysts has been conducted and monitored in an $\mathrm{O}_{2}$-equilibrated conditions and light irradiation $(\lambda \geq 320 \mathrm{~nm})$ in the absence of organic electron donors at $25{ }^{\circ} \mathrm{C}$. As shown in Fig. $5 \mathrm{~A}$, the $\mathrm{H}_{2} \mathrm{O}_{2}$ can be rapidly generated over $3 \mathrm{DOM} \mathrm{g}-\mathrm{C}_{3} \mathrm{~N}_{4}-\mathrm{PW}_{11}$ and the amounts of formed $\mathrm{H}_{2} \mathrm{O}_{2}$ can reach 3.5 $\mu \mathrm{mol}$ in $60 \mathrm{~min}$. The catalytic performance of only $3 \mathrm{DOM} \mathrm{g}-\mathrm{C}_{3} \mathrm{~N}_{4}(1.3$ $\mu \mathrm{mol}$ in $60 \mathrm{~min})$ or $\mathrm{K}-\mathrm{PW}_{11}(<0.1 \mu \mathrm{mol}$ in $60 \mathrm{~min})$ is lower than that of $3 \mathrm{DOM} \mathrm{g}-\mathrm{C}_{3} \mathrm{~N}_{4}-\mathrm{PW}_{11}(3.5 \mu \mathrm{mol}$ in $60 \mathrm{~min})$. For comparison, 3DOM g- $\mathrm{C}_{3} \mathrm{~N}_{4}-\mathrm{PW}_{11}$-IMP based on the electrostatic interaction has been prepared through the impregnation method with the same $\mathrm{PW}_{11}$ weight percentage as $3 \mathrm{DOM}$ g- $\mathrm{C}_{3} \mathrm{~N}_{4}-\mathrm{PW}_{11}$ based on covalent interaction. 3DOM g- $\mathrm{C}_{3} \mathrm{~N}_{4}-\mathrm{PW}_{11}$-IMP shows lower catalytic performance (1.5 $\mu \mathrm{mol}$ in $60 \mathrm{~min}$ ). The reaction cannot proceed in the absence of catalyst $(<0.1 \mu \mathrm{mol}$ in $60 \mathrm{~min}$ ). When extending the reaction time to $360 \mathrm{~min}$, the maximum amounts of formed $\mathrm{H}_{2} \mathrm{O}_{2}$ over $3 \mathrm{DOM}$ g- $\mathrm{C}_{3} \mathrm{~N}_{4}-\mathrm{PW}_{11}$, $3 \mathrm{DOM} \mathrm{g}-\mathrm{C}_{3} \mathrm{~N}_{4}-\mathrm{PW}_{11}-\mathrm{IMP}$ and $3 \mathrm{DOM} \mathrm{g}-\mathrm{C}_{3} \mathrm{~N}_{4}$ can be obtained as 14.4, 5.2 and $2.3 \mu \mathrm{mol}$, respectively (Fig. S9), which gives the $\mathrm{H}_{2} \mathrm{O}_{2}$ formation rate of 2.4, 0.9 and $0.4 \mu \mathrm{mol} \mathrm{h}^{-1}$ for $3 \mathrm{DOM} \mathrm{g-} \mathrm{C}_{3} \mathrm{~N}_{4}-\mathrm{PW}_{11}$, $3 \mathrm{DOM} \mathrm{g}-\mathrm{C}_{3} \mathrm{~N}_{4}-\mathrm{PW}_{11}$-IMP and $3 \mathrm{DOM}$ g- $\mathrm{C}_{3} \mathrm{~N}_{4}$.

(Table S3). Fig. S10 shows the lamellar g- $\mathrm{C}_{3} \mathrm{~N}_{4}$ shows no catalytic

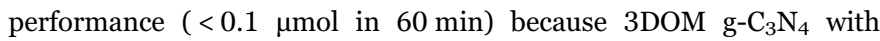
macroporous structure has large amounts of $-\mathrm{NH}_{2}$ groups that are active for light-driven $\mathrm{H}_{2} \mathrm{O}_{2}$ production (Fig. S1) [8b,29].

The formation and decomposition of $\mathrm{H}_{2} \mathrm{O}_{2}$ over catalysts proceeds through two competitive pathways owing to the thermodynamic instability of $\mathrm{H}_{2} \mathrm{O}_{2}$ at room temperature $[6 \mathrm{a}, 30]$. We therefore separately evaluates the rate constants for light-driven $\mathrm{H}_{2} \mathrm{O}_{2}$ formation and decomposition by assuming zero-order and first-order kinetics [31]:

$\left[\mathrm{H}_{2} \mathrm{O}_{2}\right]=\frac{K_{\mathrm{f}}}{K_{\mathrm{d}}}\left(1-e^{K_{\mathrm{d}^{t}}}\right)$

The $K_{\mathrm{f}}$ and $K_{\mathrm{d}}$ values have been estimated by fitting the data in
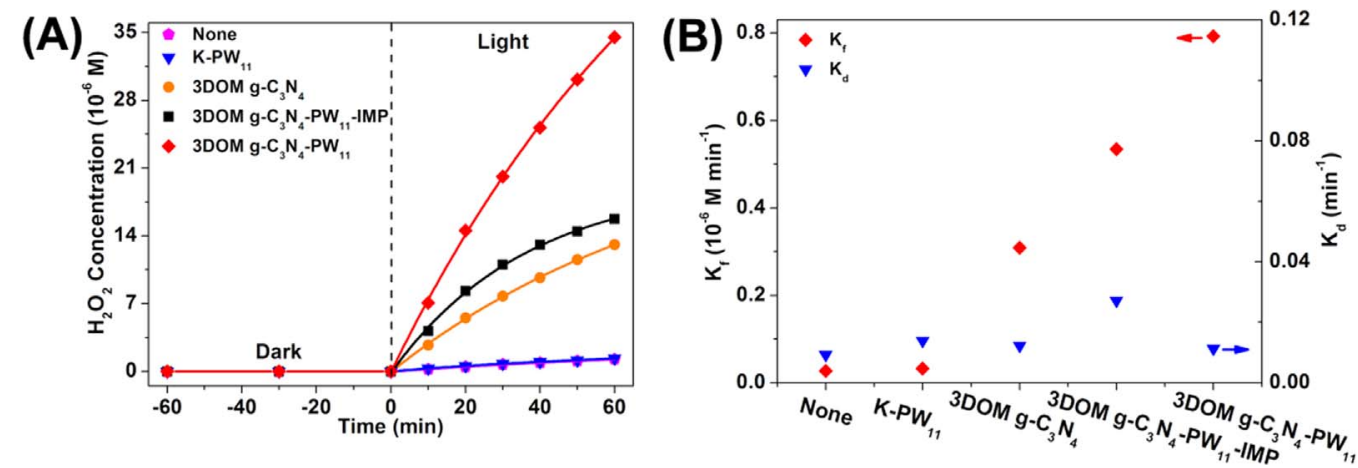

Fig. 5. Light-driven $\mathrm{H}_{2} \mathrm{O}_{2}$ formation over different catalysts in $60 \mathrm{~min}$. Reaction conditions: $\mathrm{H}_{2} \mathrm{O}(100 \mathrm{ml})$, catalyst $(0.10 \mathrm{~g}, 1 \mathrm{~g} \mathrm{~L}-1), \mathrm{O}_{2}$-equilibrated, $\lambda \geq 320 \mathrm{~nm}, 25^{\circ} \mathrm{C}$. 

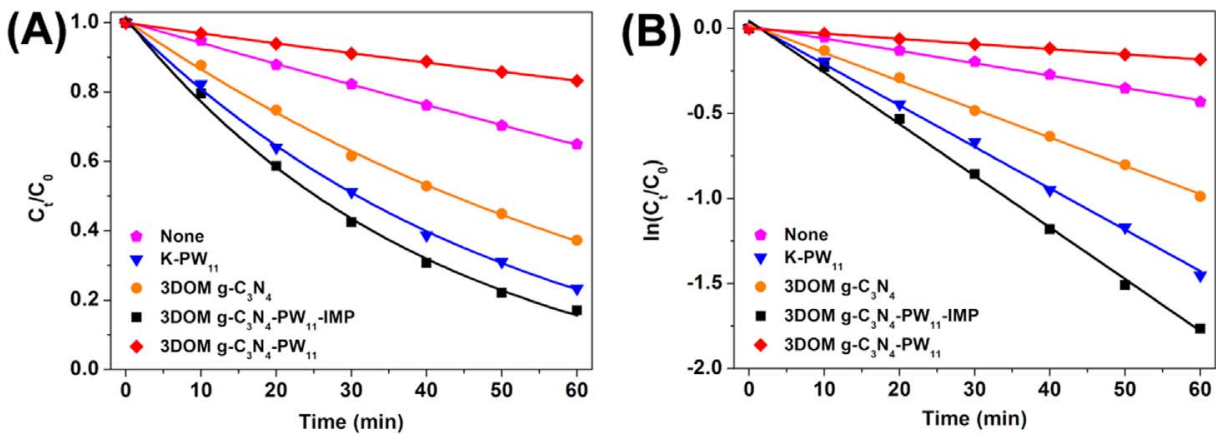

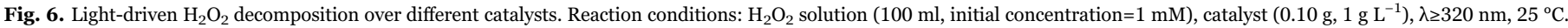

Fig. 5A according to Eq. (6) and the results are presented in Fig. 5B. After the covalent combination of $\mathrm{PW}_{11}$ cluster with $3 \mathrm{DOM} \mathrm{g-} \mathrm{C}_{3} \mathrm{~N}_{4}, K_{\mathrm{f}}$ value increases from 0.3090 to $0.7921 \mu \mathrm{M} \mathrm{min}^{-1}$ and $K_{\mathrm{d}}$ value decreases from 0.0123 to $0.0113 \mathrm{~min}^{-1}$. The above results indicate that the covalent combination of $\mathrm{PW}_{11}$ and $3 \mathrm{DOM} \mathrm{g}-\mathrm{C}_{3} \mathrm{~N}_{4}$ can enhance the $\mathrm{H}_{2} \mathrm{O}_{2}$ formation and stabilize the formed $\mathrm{H}_{2} \mathrm{O}_{2}$ under light irradiation.

The light-driven $\mathrm{H}_{2} \mathrm{O}_{2}$ decomposition over different catalysts has been conducted with an initial $\mathrm{H}_{2} \mathrm{O}_{2}$ concentration of $1 \mathrm{mM}$ to investigate the decomposition behavior of $\mathrm{H}_{2} \mathrm{O}_{2}$ in the presence of catalysts. As shown in Fig. $6 \mathrm{~A}$, the $\mathrm{H}_{2} \mathrm{O}_{2}$ decomposes about $17 \%$ over $3 \mathrm{DOM}$ g- $\mathrm{C}_{3} \mathrm{~N}_{4}-\mathrm{PW}_{11}$ after $60 \mathrm{~min}$, which is lower than those over $3 \mathrm{DOM}$ g- $\mathrm{C}_{3} \mathrm{~N}_{4}$ (63\%), K-PW 11 (77\%) and 3DOM g- $\mathrm{C}_{3} \mathrm{~N}_{4}-\mathrm{PW}_{11}$-IMP (83\%). The $\mathrm{H}_{2} \mathrm{O}_{2}$ decomposes about $35 \%$ in the absence of catalyst. Owing to the large quantity of $\mathrm{H}_{2} \mathrm{O}_{2}(1 \mathrm{mM})$ and the constant amounts of the catalysts, the decomposition is expected to follow a pseudo-firstorder reaction [32]:

$-\frac{d c_{t}}{d t}=k_{0}$

where $c_{t}$ is the $\mathrm{H}_{2} \mathrm{O}_{2}$ concentration at time $\mathrm{t}, k_{O}$ is the pseudo-firstorder rate constant, and $c_{O}$ is the initial concentration of $\mathrm{H}_{2} \mathrm{O}_{2}(1 \mathrm{mM})$ in this work. To more accurately evaluate the rate constants, we have fitted the decomposition data of different catalysts based on Eq. (7) and presented in Fig. 6B, where $K_{\mathrm{d}}{ }^{\prime}$ is the first-order reaction rate constant. The results in Table S3 indicates that the values of $K_{\mathrm{d}}$ ' increases in the

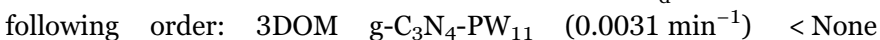
$\left(0.0073 \mathrm{~min}^{-1}\right)<3 \mathrm{DOM} \quad \mathrm{g}^{-\mathrm{C}_{3} \mathrm{~N}_{4}}\left(0.0167 \mathrm{~min}^{-1}\right) \quad<\mathrm{K}-\mathrm{PW}_{11}$ $\left(0.0243 \mathrm{~min}^{-1}\right)<3 \mathrm{DOM} \mathrm{g}-\mathrm{C}_{3} \mathrm{~N}_{4}-\mathrm{PW}_{11}$-IMP $\left(0.0304 \mathrm{~min}^{-1}\right)$. An additional concern is that the formed $\mathrm{H}_{2} \mathrm{O}_{2}$ might react with $\mathrm{PW}_{11}$ cluster to form the Ishii-Venturello polyperoxometalate species of $\left\{\mathrm{PO}_{4}\left[\mathrm{WO}\left(\mathrm{O}_{2}\right)_{2}\right]_{4}\right\}^{3-}[33]$. The ${ }^{31} \mathrm{P}$ MAS NMR for used 3DOM g- $\mathrm{C}_{3} \mathrm{~N}_{4^{-}}$ $\mathrm{PW}_{11}$ (Fig. S11) shows no signal of these species, which rules out the formation of polyperoxometalate species during the light-driven $\mathrm{H}_{2} \mathrm{O}_{2}$ production [34]. The above results confirm that the covalent combination of $\mathrm{PW}_{11}$ and $3 \mathrm{DOM} \mathrm{g}-\mathrm{C}_{3} \mathrm{~N}_{4}$ can stabilize the formed $\mathrm{H}_{2} \mathrm{O}_{2}$ under light irradiation.

It is important to note that under similar reaction conditions over the $\mathrm{g}_{-} \mathrm{C}_{3} \mathrm{~N}_{4}$-based catalysts in the absence of organic electron donors (Table 1$)$, the $\mathrm{H}_{2} \mathrm{O}_{2}$ formation rate $\left(2.4 \mu \mathrm{mol} \mathrm{h} \mathrm{h}^{-1}\right)$ over $3 \mathrm{DOM} \mathrm{g-} \mathrm{C}_{3} \mathrm{~N}_{4^{-}}$

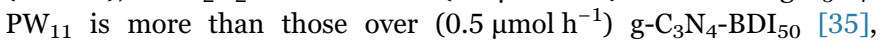
$\left(1.0 \mu \mathrm{mol} \mathrm{h}^{-1}\right) \mathrm{g}_{-} \mathrm{C}_{3} \mathrm{~N}_{4}-\mathrm{PDI}_{51}[6 \mathrm{~b}],\left(1.2 \mu \mathrm{mol} \mathrm{h}^{-1}\right) \mathrm{g}_{-} \mathrm{C}_{3} \mathrm{~N}_{4}-\mathrm{PDI}_{51}-\mathrm{rGOs}$ [6e], and $\left(1.8 \mu \mathrm{mol} \mathrm{h}^{-1}\right) \mathrm{g}-\mathrm{C}_{3} \mathrm{~N}_{4}-\mathrm{NiFeO}$ [32], but inferior to that $\left(9.2 \mu \mathrm{mol} \mathrm{h}{ }^{-1}\right)$ over $\mathrm{Cv}-\mathrm{g}-\mathrm{C}_{3} \mathrm{~N}_{4}[8 \mathrm{~b}]$. Though $\mathrm{Cv}-\mathrm{g}-\mathrm{C}_{3} \mathrm{~N}_{4}$ shows better catalytic performance for two-electron $\mathrm{O}_{2}$ reduction to $\mathrm{H}_{2} \mathrm{O}_{2}$ than $3 \mathrm{DOM} \mathrm{g}-\mathrm{C}_{3} \mathrm{~N}_{4}-\mathrm{PW}_{11}$, the ability of water oxidation for $\mathrm{Cv}-\mathrm{g}-\mathrm{C}_{3} \mathrm{~N}_{4}$ is negligible where $\mathrm{H}_{2} \mathrm{O}_{2}$ cannot be detected under Ar-equilibrated

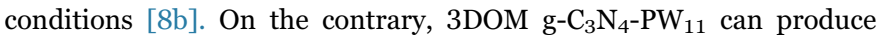
considerable amounts of $\mathrm{H}_{2} \mathrm{O}_{2}(1.5 \mu \mathrm{mol}$ in $60 \mathrm{~min})$ under $\mathrm{N}_{2}$-equilibrated conditions (Fig. S12), indicating the $3 \mathrm{DOM}$ g- $\mathrm{C}_{3} \mathrm{~N}_{4}-\mathrm{PW}_{11}$ can act as a dual-functional catalyst for both water oxidation and oxygen reduction [32]. Nevertheless, the $\mathrm{H}_{2} \mathrm{O}_{2}$ formation rate $\left(2.4 \mu \mathrm{mol} \mathrm{h}{ }^{-1}\right)$
Table 1

Comparison of the maximum formed $\mathrm{H}_{2} \mathrm{O}_{2}$ amounts ( $\mu \mathrm{mol}$ ) and $\mathrm{H}_{2} \mathrm{O}_{2}$ formation rate $\left(\mu \mathrm{mol} \mathrm{h}{ }^{-1}\right)$ over $\mathrm{g}-\mathrm{C}_{3} \mathrm{~N}_{4}$-based photocatalyst.

\begin{tabular}{|c|c|c|c|}
\hline Catalyst & $\begin{array}{l}\text { Maximum formed } \\
\mathrm{H}_{2} \mathrm{O}_{2}(\mu \mathrm{mol})\end{array}$ & $\begin{array}{l}\mathrm{H}_{2} \mathrm{O}_{2} \text { Formation Rate } \\
\left(\mu \mathrm{mol} \mathrm{h}{ }^{-1}\right)\end{array}$ & Refs. \\
\hline $\begin{array}{l}3 \mathrm{DOM} \mathrm{g-C} \mathrm{C}_{4}- \\
\mathrm{PW}_{11}\end{array}$ & 14.4 & 2.4 & $\begin{array}{l}\text { This } \\
\text { work }\end{array}$ \\
\hline $\mathrm{g}-\mathrm{C}_{3} \mathrm{~N}_{4}-\mathrm{BDI}_{50}^{\mathrm{a}}$ & 11.6 & 0.5 & [35] \\
\hline $\mathrm{g}-\mathrm{C}_{3} \mathrm{~N}_{4}-\mathrm{PDI}_{51} \mathrm{~b}$ & 50.6 & 1.0 & [6b] \\
\hline $\begin{array}{l}\mathrm{g}-\mathrm{C}_{3} \mathrm{~N}_{4}-\mathrm{PDI}_{51^{-}} \\
\mathrm{rGOs}^{\mathrm{c}}\end{array}$ & 30.0 & 1.2 & {$[6 \mathrm{e}]$} \\
\hline $\mathrm{g}-\mathrm{C}_{3} \mathrm{~N}_{4}-\mathrm{NiFeO}$ & 1.8 & 1.8 & [32] \\
\hline $\mathrm{Cv}-\mathrm{g}-\mathrm{C}_{3} \mathrm{~N}_{4}{ }^{\mathrm{d}}$ & 9.2 & 9.2 & {$[8 \mathrm{~b}]$} \\
\hline
\end{tabular}

${ }^{\text {a }}$ BDI=biphenyl diimide;

${ }^{\mathrm{b}}$ PDI=pyromellitic diimide;

${ }^{\mathrm{c}}$ rGOs=reduced graphene oxide;

${ }^{\mathrm{d}} \mathrm{Cv}-\mathrm{g}-\mathrm{C}_{3} \mathrm{~N}_{4}=$ carbon vacancy contained $\mathrm{g}-\mathrm{C}_{3} \mathrm{~N}_{4}$.

over 3DOM g- $\mathrm{C}_{3} \mathrm{~N}_{4}-\mathrm{PW}_{11}$ is more than those $\left(2.3 \mu \mathrm{mol} \mathrm{h}{ }^{-1}\right)$ over $\mathrm{TiO}_{2^{-}}$ CoPi-rGOs [6a] and $\left(0.5 \mu \mathrm{mol} \mathrm{h}{ }^{-1}\right)$ over CdS-rGOs 20 [6f]. Therefore, the relative high $\mathrm{H}_{2} \mathrm{O}_{2}$ formation rate among the reported catalysts make 3DOM g- $\mathrm{C}_{3} \mathrm{~N}_{4}-\mathrm{PW}_{11}$ a promising catalyst for light-driven $\mathrm{H}_{2} \mathrm{O}_{2}$ production in the absence of organic electron donors.

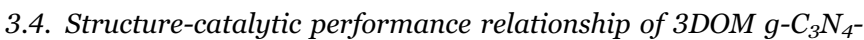 $P W_{11}$}

Photoelectrochemical characterization should be performed to clarify the reason for the efficient activity of $3 \mathrm{DOM} \mathrm{g}-\mathrm{C}_{3} \mathrm{~N}_{4}-\mathrm{PW}_{11}$. The catalysts of $3 \mathrm{DOM} \mathrm{g}-\mathrm{C}_{3} \mathrm{~N}_{4}$ and $3 \mathrm{DOM}$ g- $\mathrm{C}_{3} \mathrm{~N}_{4}-\mathrm{PW}_{11}$ have been casted on fluorine-doped tin oxide (FTO) electrodes and these electrodes have been used in a three-electrode electrochemical cell [32]. As shown in Fig. S13A, the photo-current density of $3 \mathrm{DOM}$ g- $\mathrm{C}_{3} \mathrm{~N}_{4}-\mathrm{PW}_{11}$ $\left(0.43 \mu \mathrm{A} \mathrm{cm}^{-2}\right)$ is much larger than that of $3 \mathrm{DOM} \mathrm{g}_{-} \mathrm{C}_{3} \mathrm{~N}_{4}$ $\left(0.01 \mu \mathrm{A} \mathrm{cm}^{-2}\right)$. Photoelectrochemical impedance spectroscopy (EIS) results are shown in Fig. S13B. The diameter of Nyquist semicircle for $3 \mathrm{DOM} \mathrm{g}-\mathrm{C}_{3} \mathrm{~N}_{4}-\mathrm{PW}_{11}$ is smaller than that of $3 \mathrm{DOM} \mathrm{g}-\mathrm{C}_{3} \mathrm{~N}_{4}$, which indicates that the $3 \mathrm{DOM}$ g- $\mathrm{C}_{3} \mathrm{~N}_{4}-\mathrm{PW}_{11}$ composites have lower resistances than $3 \mathrm{DOM} \mathrm{g}-\mathrm{C}_{3} \mathrm{~N}_{4}$. The above results reveal that the covalent combination of $\mathrm{PW}_{11}$ and $3 \mathrm{DOM}$ g- $\mathrm{C}_{3} \mathrm{~N}_{4}$ can enhance the charge separation of 3DOM g- $\mathrm{C}_{3} \mathrm{~N}_{4}-\mathrm{PW}_{11}$. Photoluminescence (PL) spectrum has been used to explore the recombination and separation of photogenerated electrons and holes in the $3 \mathrm{DOM} \mathrm{g}-\mathrm{C}_{3} \mathrm{~N}_{4}$ and $3 \mathrm{DOM}$ g- $\mathrm{C}_{3} \mathrm{~N}_{4}-$ $\mathrm{PW}_{11}$ (Fig. S14A). The emission peak appearing at about $485 \mathrm{~nm}$ is attributed to the direct electron-hole recombination of band transition. Compare with $3 \mathrm{DOM}$ g- $\mathrm{C}_{3} \mathrm{~N}_{4}, 3 \mathrm{DOM}$ g- $\mathrm{C}_{3} \mathrm{~N}_{4}-\mathrm{PW}_{11}$ possess a weaker emission peak, confirming the above photo-current and EIS results.

The above catalytic and characterization results indicate that the covalent combination of $\mathrm{PW}_{11}$ cluster and $3 \mathrm{DOM}$ g- $\mathrm{C}_{3} \mathrm{~N}_{4}$ can enhance charge separation and thus facilitate the light-driven formation of $\mathrm{H}_{2} \mathrm{O}_{2}$. Furthermore, the above results also suggest that the 3DOM g$\mathrm{C}_{3} \mathrm{~N}_{4}-\mathrm{PW}_{11}$ can act as a dual-functional catalyst for both water 

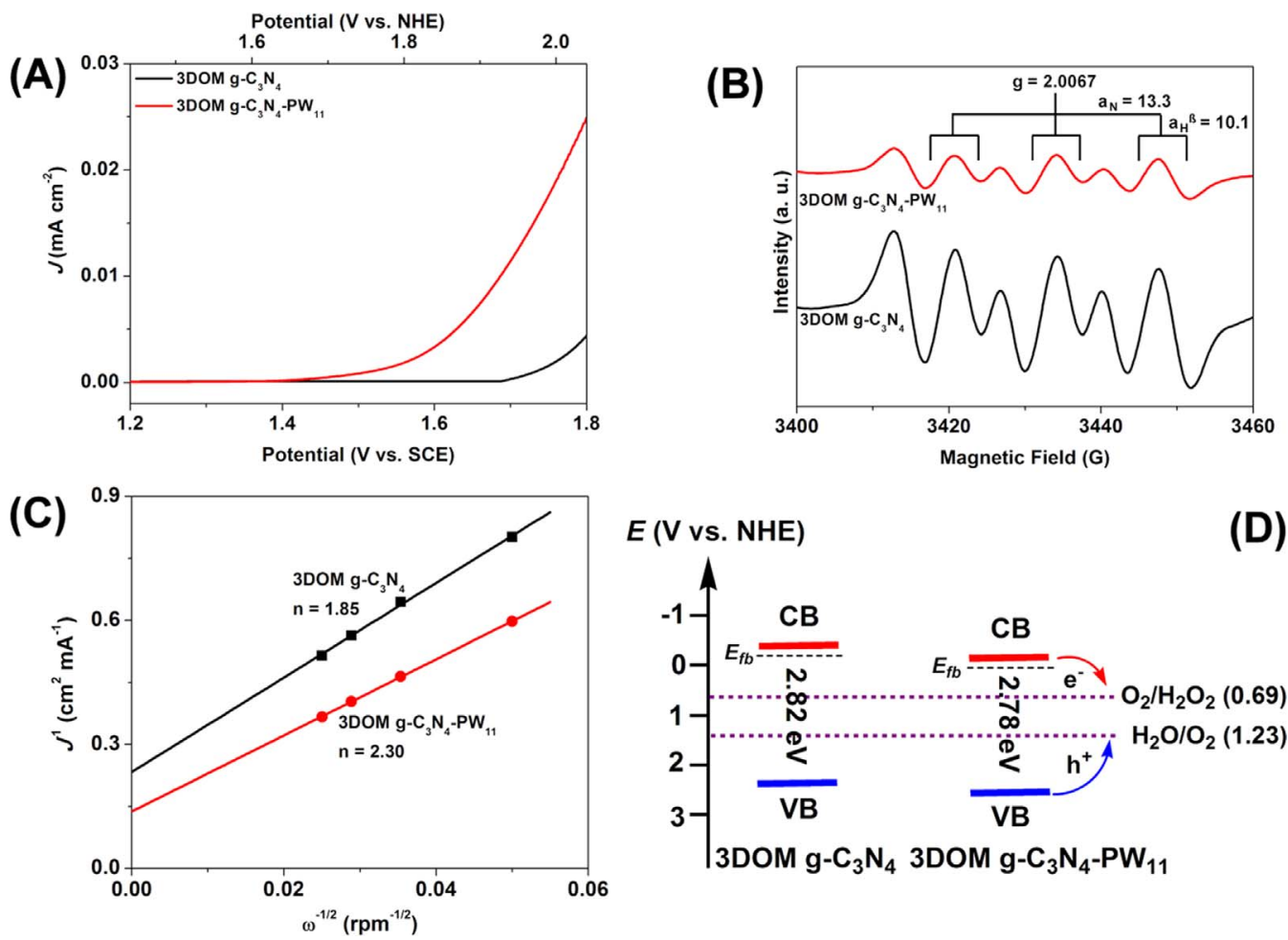

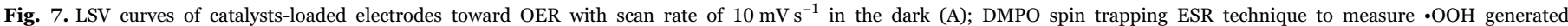

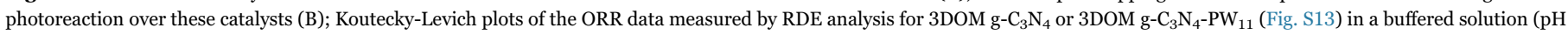
7) at a constant potential of $-0.9 \mathrm{~V}$ vs $\mathrm{Ag} / \mathrm{AgCl}(\mathrm{C})$; and scheme of energy levels and charge transfer pathways of $3 \mathrm{DOM}$ g- $\mathrm{C}_{3} \mathrm{~N}_{4}$ and $3 \mathrm{DOM}$ g- $\mathrm{C}_{3} \mathrm{~N}_{4}-\mathrm{PW} \mathrm{W}_{11}(\mathrm{D})$.

oxidation and oxygen reduction. Therefore, the catalytic performance for water oxidation and oxygen reduction should be investigated. The water oxidation performance has been evaluated by oxygen evolution reaction (OER) [6a,32]. Fig. 7A shows linear sweep voltammogram (LSV) curves of the electrodes with the $3 \mathrm{DOM} \mathrm{g-} \mathrm{C}_{3} \mathrm{~N}_{4}$ and $3 \mathrm{DOM} \mathrm{g}-$ $\mathrm{C}_{3} \mathrm{~N}_{4}-\mathrm{PW}_{11}$ in the dark. The onset potential of $3 \mathrm{DOM}$ g- $\mathrm{C}_{3} \mathrm{~N}_{4}$ is at approximately $1.93 \mathrm{~V}$ vs. normal hydrogen electrode (NHE) in the dark, which had a $0.70 \mathrm{~V}$ overpotential because the thermodynamic potential was $1.23 \mathrm{~V}$ vs. NHE. In addition, the slow increase of the current density $(J)$ with bias $(E)$ indicated a high kinetic barrier. In contrast, for $3 \mathrm{DOM} \mathrm{g}-\mathrm{C}_{3} \mathrm{~N}_{4}-\mathrm{PW}_{11}$, the onset potential negatively shifted to $1.63 \mathrm{~V}$ vs. NHE, and the current density was greatly enhanced compared to the $3 \mathrm{DOM} \mathrm{g-} \mathrm{C}_{3} \mathrm{~N}_{4}$. The above results reveal that the OER performance of $3 \mathrm{DOM} \mathrm{g}-\mathrm{C}_{3} \mathrm{~N}_{4}-\mathrm{PW}_{11}$ is higher than that of 3DOM g$\mathrm{C}_{3} \mathrm{~N}_{4}$. ESR analysis with 5,5-dimethyl-1-pyrroline $\mathrm{N}$-oxide (DMPO) as a spin-trapping reagent has been performed to confirm the pathway of $\mathrm{O}_{2}$ reduction over different catalysts. Fig. 7B shows the ESR spectrum of the solutions recovered after photoreaction over $3 \mathrm{DOM} \mathrm{g-} \mathrm{C}_{3} \mathrm{~N}_{4}$ and $3 \mathrm{DOM}$ g- $\mathrm{C}_{3} \mathrm{~N}_{4}-\mathrm{PW}_{11}$ for $3 \mathrm{~min}$. Both solutions exhibit distinctive signals assigned to the DMPO- $\bullet \mathrm{OOH}$ spin adduct $\left(\alpha_{\mathrm{N}}=13.3 \mathrm{G}\right.$, $\alpha_{H}^{\beta}=10.1 \mathrm{G}, \mathrm{g}=2.0065$ ) [8a]. The signal intensity for the solution obtained by photoreaction over $3 \mathrm{DOM}$ g- $\mathrm{C}_{3} \mathrm{~N}_{4}-\mathrm{PW}_{11}$ is much weaker than that over $3 \mathrm{DOM} g-\mathrm{C}_{3} \mathrm{~N}_{4}$. The results suggest that one-electron reduction of $\mathrm{O}_{2}$ (Eq. (4)) is indeed suppressed over $3 \mathrm{DOM} \mathrm{g-} \mathrm{C}_{3} \mathrm{~N}_{4}$ $\mathrm{PW}_{11}$, and thus promotes the two-electron reduction of $\mathrm{O}_{2}$ (Eq. (3)).

Electrochemical rotating disk electrode (RDE) analysis of oxygen reduction reaction (ORR) further investigates the pathway of $\mathrm{O}_{2}$ reduction. Fig. S15 shows the LSV curves of $3 \mathrm{DOM} g-\mathrm{C}_{3} \mathrm{~N}_{4}$ and $3 \mathrm{DOM} \mathrm{g}-\mathrm{C}_{3} \mathrm{~N}_{4}-\mathrm{PW}_{11}$ measured on $\mathrm{RDE}$ in an $\mathrm{O}_{2}$-saturated $0.1 \mathrm{M}$ phosphate buffer solution $(\mathrm{pH} 7)$ at different rotating speeds. Fig. $7 \mathrm{C}$ summarizes the Koutecky-Levich plots of the data at $-0.9 \mathrm{~V}$ vs. $\mathrm{Ag} /$ $\mathrm{AgCl}$. The average number of electrons (n) involved in the overall $\mathrm{O}_{2}$ reduction can be estimated by the linear regression of the plots using the following equations [36]:

$$
\begin{aligned}
& j^{-1}=j_{k}^{-1}+B^{-1} \omega^{-1 / 2} \\
& \mathrm{~B}=0.2 n F \nu^{-1 / 6} C D^{2 / 3}
\end{aligned}
$$

$j$ is the current density, $j_{\mathrm{k}}$ is the kinetic current density, $\omega$ is the rotating speed (rpm), $F$ is the Faraday constant $\left(96485 \mathrm{C} \mathrm{mol}^{-1}\right), v$ is the kinetic viscosity of water $\left(0.01 \mathrm{~cm}^{2} \mathrm{~s}^{-1}\right), \mathrm{C}$ is the bulk concentration of $\mathrm{O}_{2}$ in water $\left(1.26 \times 10^{-3} \mathrm{~mol} \mathrm{~cm}^{-3}\right)$, and $D$ is the diffusion coefficient of $\mathrm{O}_{2}$ $\left(2.7 \times 10^{-5} \mathrm{~cm}^{2} \mathrm{~s}^{-1}\right)$, respectively [37]. The $\mathrm{n}$ value for $3 \mathrm{DOM} \mathrm{g}_{3} \mathrm{C}_{3}$ $(\mathrm{n}=1.85)$ suggests that one-electron $\mathrm{O}_{2}$ reduction indeed occurs, which confirms the ESR results. In contrast, $3 \mathrm{DOM}$ g- $\mathrm{C}_{3} \mathrm{~N}_{4}-\mathrm{PW}_{11}$ exhibits $\mathrm{n}=2.30$, indicating the covalent combination of $3 \mathrm{DOM} g-\mathrm{C}_{3} \mathrm{~N}_{4}$ and $\mathrm{PW}_{11}$ can selectively promote the two-electron $\mathrm{O}_{2}$ reduction. It has been reported that the enhanced $\mathrm{O}_{2}$ adsorption of catalysts can promote the multi-electron reduction of $\mathrm{O}_{2}[36,38]$. Furthermore, $\mathrm{O}_{2}$ temperature programmed desorption $\left(\mathrm{O}_{2}\right.$-TPD) has been performed to detect the changes of oxygen species after the covalent combination (Fig. S16). The oxygen desorption at low temperature $\left(<400{ }^{\circ} \mathrm{C}\right)$ is ascribed to adsorbed oxygen $\left(\mathrm{O}_{\text {ads }}\right)$, and the lattice oxygen $\left(\mathrm{O}_{\text {latt }}\right)$ starts to be released at high temperature $\left(>400{ }^{\circ} \mathrm{C}\right)$ [27]. The oxygen desorption at $341{ }^{\circ} \mathrm{C}$ can only be observed in 3DOM g- $\mathrm{C}_{3} \mathrm{~N}_{4}-\mathrm{PW}_{11}$, indicating the amounts of $\mathrm{O}_{\text {ads }}$ in $3 \mathrm{DOM} \mathrm{g}-\mathrm{C}_{3} \mathrm{~N}_{4}-\mathrm{PW}_{11}$ are much more than those in $3 \mathrm{DOM} \mathrm{g}-\mathrm{C}_{3} \mathrm{~N}_{4}$ and $\mathrm{K}-\mathrm{PW}_{11}$. Combing the ESR, KouteckyLevich plots and $\mathrm{O}_{2}$-TPD results, the enhanced $\mathrm{O}_{2}$ adsorption of 3DOM g- $\mathrm{C}_{3} \mathrm{~N}_{4}-\mathrm{PW}_{11}$ can selectively promote the two-electron reduction of $\mathrm{O}_{2}$ to $\mathrm{H}_{2} \mathrm{O}_{2}$.

The flat band potentials $\left(E_{\mathrm{fb}}\right)$ of $3 \mathrm{DOM} \mathrm{g-} \mathrm{C}_{3} \mathrm{~N}_{4}$ and $3 \mathrm{DOM} \mathrm{g-} \mathrm{C}_{3} \mathrm{~N}_{4}-$ $\mathrm{PW}_{11}$ casted on FTO has been estimated by electrochemical MottSchottky measurements at varied frequencies $(1.0,1.5$ and $2.0 \mathrm{kHz})$. The Mott-Schottky plots of both catalysts exhibit positive slopes (Fig. S17A and B), suggestive of their n-type semiconductor features [39]. The $E_{\mathrm{fb}}$ values have been estimated by extrapolating the linear portion of the curve to intercept of the $X$-axis [40]. A flat band potential of $-0.15 \mathrm{~V}$ and $0.06 \mathrm{~V}$ vs. NHE has been obtained for 3DOM g- $\mathrm{C}_{3} \mathrm{~N}_{4}$ and $3 \mathrm{DOM}$ g- $\mathrm{C}_{3} \mathrm{~N}_{4}-\mathrm{PW}_{11}$, respectively. The conduction band could be $0-$ $0.1 \mathrm{~V}$ more negative than the flat band position. Hence, the corre- 

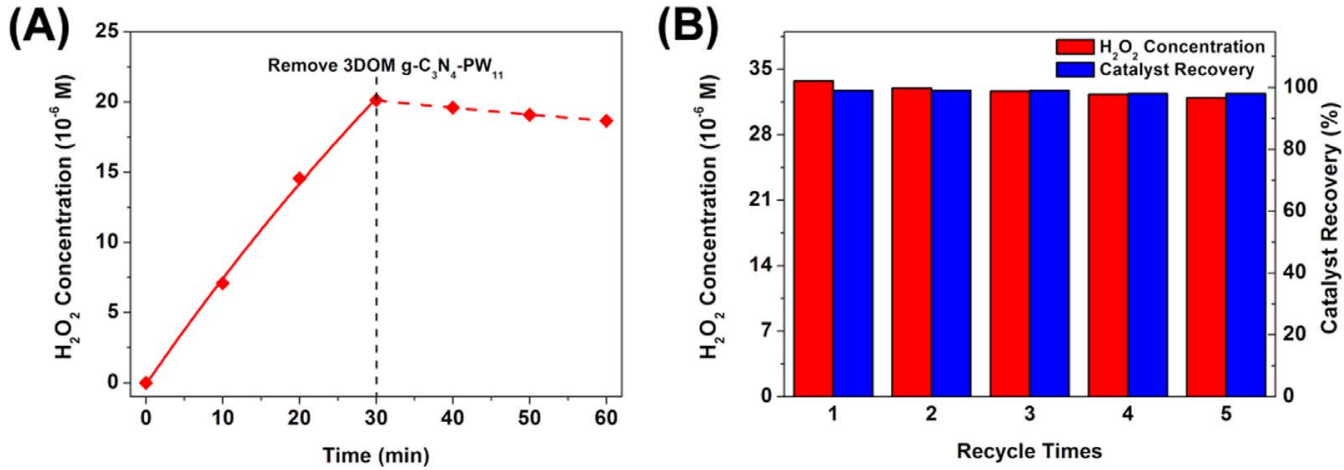

Fig. 8. Experiment to prove the heterogeneous nature (A) and the recycle (B) of $3 D O M$ g- $\mathrm{C}_{3} \mathrm{~N}_{4}-\mathrm{PW}_{11}$.

sponding $\mathrm{CB}$ edge of $3 \mathrm{DOM} g-\mathrm{C}_{3} \mathrm{~N}_{4}$ and $3 \mathrm{DOM} g-\mathrm{C}_{3} \mathrm{~N}_{4}-\mathrm{PW}_{11}$ has been estimated to be $-0.25 \mathrm{~V}$ and $-0.04 \mathrm{~V}$ vs. NHE, respectively. A positive shift of $0.21 \mathrm{~V}$ from $3 \mathrm{DOM} g-\mathrm{C}_{3} \mathrm{~N}_{4}$ to $3 \mathrm{DOM} g-\mathrm{C}_{3} \mathrm{~N}_{4}-\mathrm{PW}_{11}$ has been observed. The positive shift of the $\mathrm{CB}$ in $3 \mathrm{DOM}$ g- $\mathrm{C}_{3} \mathrm{~N}_{4}-\mathrm{PW}_{11}$ is likely to improve the selectivity of $\mathrm{O}_{2}$ reduction to $\mathrm{H}_{2} \mathrm{O}_{2}$ [6e]. The Tauc plots of $3 \mathrm{DOM} \mathrm{g}-\mathrm{C}_{3} \mathrm{~N}_{4}$ and $3 \mathrm{DOM}$ g- $\mathrm{C}_{3} \mathrm{~N}_{4}-\mathrm{PW}_{11}$ have been derived according to the relationship of $(\mathrm{F}(\mathrm{R}) \cdot \mathrm{h} v)^{2}=\mathrm{A}\left(\mathrm{h} v-E_{\mathrm{g}}\right)$, where $\mathrm{h}$ is Plank's constant, $v$ is the frequency, $\mathrm{A}$ is a constant, and $E_{\mathrm{g}}$ is the material band gap (Fig. S14C) [41]. From the Tauc plots, the band gap of 3DOM g$\mathrm{C}_{3} \mathrm{~N}_{4}$ and $3 \mathrm{DOM} \mathrm{g}-\mathrm{C}_{3} \mathrm{~N}_{4}-\mathrm{PW}_{11}$ are 2.82 and $2.78 \mathrm{eV}$, respectively.

Combining the Mott-Schottky measurements and Tauc plots results, the VB positions of $3 \mathrm{DOM} \mathrm{g}-\mathrm{C}_{3} \mathrm{~N}_{4}$ and $3 \mathrm{DOM} \mathrm{g}-\mathrm{C}_{3} \mathrm{~N}_{4}-\mathrm{PW}_{11}$ have been estimated as $2.57 \mathrm{~V}$ and $2.74 \mathrm{~V}$ vs. NHE, respectively. As shown in Fig. $7 \mathrm{D}$, both the $\mathrm{CB}$ and $\mathrm{VB}$ of $3 \mathrm{DOM}$ g- $\mathrm{C}_{3} \mathrm{~N}_{4}-\mathrm{PW}_{11}$ are more positive than those of $3 \mathrm{DOM} g-\mathrm{C}_{3} \mathrm{~N}_{4}$. Because the water oxidation is a ratelimiting step, the positive shift of the VB in $3 \mathrm{DOM}$ g- $\mathrm{C}_{3} \mathrm{~N}_{4}-\mathrm{PW}_{11}$ facilitates to overcome the kinetic barrier of the $\mathrm{O}_{2}$ evolution. Moreover, the CB level in $3 \mathrm{DOM} g-\mathrm{C}_{3} \mathrm{~N}_{4}-\mathrm{PW}_{11}(-0.04 \mathrm{~V}$ vs. NHE) is more positive than the one-electron reduction of $\mathrm{O}_{2}$ to $\cdot \mathrm{OOH}(-0.13 \mathrm{~V}$ vs. NHE), and has sufficient potential difference $(0.73 \mathrm{~V})$ from the twoelectron reduction of $\mathrm{O}_{2}$ to $\mathrm{H}_{2} \mathrm{O}_{2}(0.69 \mathrm{~V}$ vs. NHE) [42]. The results are in accordance with the reported $g-\mathrm{C}_{3} \mathrm{~N}_{4}$-PDI and $\mathrm{g}-\mathrm{C}_{3} \mathrm{~N}_{4}-\mathrm{NiFeO}$ catalysts, in which both the $\mathrm{CB}$ and VB levels of g- $\mathrm{C}_{3} \mathrm{~N}_{4}$-PDI and g$\mathrm{C}_{3} \mathrm{~N}_{4}-\mathrm{NiFeO}$ are shifted positively [6e,32]. In these catalytic systems, the positive shifts of $\mathrm{VB}$ have proved to enhance the capability of $3 \mathrm{DOM} \mathrm{g}-\mathrm{C}_{3} \mathrm{~N}_{4}-\mathrm{PW}_{11}$ for water oxidation and promote the two-electron reduction of $\mathrm{O}_{2}$ to $\mathrm{H}_{2} \mathrm{O}_{2}$.

\subsection{Recycle of heterogeneous $3 \mathrm{DOM} \mathrm{g-} \mathrm{C}_{3} \mathrm{~N}_{4}-\mathrm{P} W_{11}$}

It is essential to confirm the catalysis of $3 \mathrm{DOM} \mathrm{g}-\mathrm{C}_{3} \mathrm{~N}_{4}-\mathrm{PW}_{11}$ is truly heterogeneous for light- driven $\mathrm{H}_{2} \mathrm{O}_{2}$ production. When the reaction time arrives at $30 \mathrm{~min}, 3 \mathrm{DOM} \mathrm{g}-\mathrm{C}_{3} \mathrm{~N}_{4}-\mathrm{PW}_{11}$ has been removed from the reaction system by filtration, and the reaction is allowed to proceed with the filtrate under the same conditions as shown in Fig. $8 \mathrm{~A}$, no new $\mathrm{H}_{2} \mathrm{O}_{2}$ forms and the formed $\mathrm{H}_{2} \mathrm{O}_{2}$ starts to decompose under the same conditions. Furthermore, the ICP-AES result reveals no $\mathrm{W}$ leaching in the filtrate. The above results rule out the contribution of $\mathrm{W}$ species leached into the reaction solution for the observed catalytic results and confirm the $3 \mathrm{DOM} \mathrm{g-} \mathrm{C}_{3} \mathrm{~N}_{4}-\mathrm{PW}_{11}$ is truly heterogeneous for $\mathrm{H}_{2} \mathrm{O}_{2}$ production.

To investigate the stability of heterogeneous 3DOM g- $\mathrm{C}_{3} \mathrm{~N}_{4}-\mathrm{PW}_{11}$, the light-driven production of $\mathrm{H}_{2} \mathrm{O}_{2}$ has been recycled for five times under the same conditions. Fig. $8 \mathrm{~B}$ shows the catalytic performance is almost unchanged and the catalyst recovery can reach above $96 \%$ even after five times. The XRD, IR, ${ }^{13} \mathrm{C},{ }^{29} \mathrm{Si}$ and ${ }^{31} \mathrm{P}$ MAS NMR spectra of the fresh and used $3 \mathrm{DOM}$ g- $\mathrm{C}_{3} \mathrm{~N}_{4}-\mathrm{PW}_{11}$ exhibits almost the same typical peaks (Figs. S11, S18 and S19). The STEM-Mapping results of the used 3DOM g- $\mathrm{C}_{3} \mathrm{~N}_{4}-\mathrm{PW}_{11}$ (Fig. S20) indicates that the macroporous structure and the dispersion of $\mathrm{PW}_{11}$ cluster on $3 \mathrm{DOM} \mathrm{g}-\mathrm{C}_{3} \mathrm{~N}_{4}$ are retained after reaction. The EA and ICP results in Table $\mathrm{S} 2$ also reveal that the composition of the used 3DOM g- $\mathrm{C}_{3} \mathrm{~N}_{4}-\mathrm{PW}_{11}$ remains unchanged. The above results indicate that the heterogeneous 3DOM g$\mathrm{C}_{3} \mathrm{~N}_{4}-\mathrm{PW}_{11}$ is catalytic stable.

\section{Conclusions}

To summarize, the hybrid catalyst of $3 \mathrm{DOM}$ g- $\mathrm{C}_{3} \mathrm{~N}_{4}-\mathrm{PW}_{11}$ with well-defined and stable structure has been prepared by covalent combining the $\mathrm{PW}_{11}$ cluster with $3 \mathrm{DOM}$ g- $\mathrm{C}_{3} \mathrm{~N}_{4}$ through the organic linker strategy. The organosilicon agent of (triethoxysilyl)-propyl isocyanate can act as the linker to covalent combine the $\mathrm{PW}_{11}$ cluster with $3 \mathrm{DOM} g-\mathrm{C}_{3} \mathrm{~N}_{4}$. The hybrid catalyst of $3 \mathrm{DOM}$ g- $\mathrm{C}_{3} \mathrm{~N}_{4}-\mathrm{PW}_{11}$ exhibits efficient catalytic performance for light-driven $\mathrm{H}_{2} \mathrm{O}_{2}$ production from $\mathrm{H}_{2} \mathrm{O}$ and $\mathrm{O}_{2}$ in the absence of organic electron donors. The catalytic and characterization results suggest the three reasons for the efficient catalytic performance of $3 \mathrm{DOM} g-\mathrm{C}_{3} \mathrm{~N}_{4}-\mathrm{PW}_{11}$ : 1) the covalent combination of $\mathrm{PW}_{11}$ cluster and $3 \mathrm{DOM}$ g- $\mathrm{C}_{3} \mathrm{~N}_{4}$ can enhance the charge separation of photogenerated holes and electrons; 2) the more positive potential of the valence band (VB) after the covalent combination can elevate photogenerated holes separation and involvement in water oxidation; 3) the conduction band (CB) level of 3DOM g- $\mathrm{C}_{3} \mathrm{~N}_{4}$ $\mathrm{PW}_{11}(-0.04 \mathrm{~V}$ vs. NHE) is more positive than that of the one-electron reduction of $\mathrm{O}_{2}$ to $\cdot \mathrm{OOH}(-0.13 \mathrm{~V}$ vs. NHE) and the potential difference between the CB level of 3DOM g- $\mathrm{C}_{3} \mathrm{~N}_{4}-\mathrm{PW}_{11}(-0.04 \mathrm{~V}$ vs. NHE) and $\mathrm{O}_{2}$ to $\mathrm{H}_{2} \mathrm{O}_{2}$ potential $(0.69 \mathrm{~V}$ vs. NHE) is sufficient $(0.73 \mathrm{~V})$, which can promote the two-electron reduction of $\mathrm{O}_{2}$ to $\mathrm{H}_{2} \mathrm{O}_{2}$. In addition, the recycle experiment results reveal that the heterogeneous $3 \mathrm{DOM}$ g- $\mathrm{C}_{3} \mathrm{~N}_{4}-\mathrm{PW}_{11}$ is catalytic stable. The covalent combination of POMs and $\mathrm{g}-\mathrm{C}_{3} \mathrm{~N}_{4}$ opens the door for further exploration and design of multifunctional catalytic materials tailored for specific applications.

\section{Acknowledgments}

This work is supported by the National Natural Science Foundations of China (Grant no. 21377148, 51438011) and the Chinese Academy of Sciences (QYZDB-SSW-DQC018).

\section{Appendix A. Supplementary material}

Supplementary data associated with this article can be found in the online version at doi:10.1016/j.nanoen.2017.04.017.

\section{References}

[1] (a) K. Sato, M. Aoki, R. Noyori, Science 281 (1998) 1646-1647;

(b) S. Niwa, M. Eswaramoorthy, J. Nair, A. Raj, N. Itoh, H. Shoji, T. Namba, F. Mizukami, Science 295 (2002) 105-107.

[2] J.M. Campos-Martin, G. Blanco-Brieva, J.L.G. Fierro, Angew. Chem. Int. Ed. 45 (2006) 6962-6984.

[3] R. Hage, A. Lienke, Angew. Chem. Int. Ed. 45 (2006) 206-222. 
[4] S.A. Mousavi Shaegh, N.T. Nguyen, S.M. Mousavi Ehteshami, S.H. Chan, Energy Environ. Sci. 5 (2012) 8225-8228.

[5] (a) F. Sandelin, P. Oinas, T. Salmi, J. Paloniemi, H. Haario, Ind. Eng. Chem. Res. 45 (2006) 986-992;

(b) J.K. Edwards, G.J. Hutchings, Angew. Chem. Int. Ed. 47 (2008) 9192-9198.

6] (a) G.H. Moon, W. Kim, A.D. Bokare, N.E. Sung, W. Choi, Energy Environ. Sci. 7 (2014) 4023-4028;

(b) Y. Shiraishi, S. Kanazawa, Y. Kofuji, H. Sakamoto, S. Ichikawa, S. Tanaka, T. Hirai, Angew. Chem. Int. Ed. 53 (2014) 13454-13459;

(c) M. Jakešová, D.H. Apaydin, M. Sytnyk, K. Oppelt, W. Heiss, N.S. Sariciftci, E.D. Głowacki, Adv. Funct. Mater. 26 (2016) 5248-5254;

(d) Y. Kofuji, Y. Isobe, Y. Shiraishi, H. Sakamoto, S. Tanaka, S. Ichikawa, T. Hirai, J. Am. Chem. Soc. 138 (2016) 10019-10025;

(e) S. Thakur, T. Kshetri, N.H. Kim, J.H. Lee, J. Catal. 345 (2017) 78-86.

[7] (a) Y. Zheng, L. Lin, B. Wang, X. Wang, Angew. Chem. Int. Ed. 54 (2015) $12868-12884$

(b) W.J. Ong, L.L. Tan, Y.H. Ng, S.T. Yong, S.P. Chai, Chem. Rev. 116 (2016) 7159-7329.

[8] (a) Y. Shiraishi, Y. Kofuji, H. Sakamoto, S. Tanaka, S. Ichikawa, T. Hirai, ACS Catal. 5 (2015) 3058-3066;

(b) S. Li, G. Dong, R. Hailili, L. Yang, Y. Li, F. Wang, Y. Zeng, C. Wang, Appl. Catal. B: Environ. 190 (2016) 26-35.

[9] (a) H. Wang, L. Zhang, Z. Chen, J. Hu, S. Li, Z. Wang, J. Liu, X. Wang, Chem. Soc. Rev. 43 (2014) 5234-5244;

(b) X. Meng, L. Liu, S. Ouyang, H. Xu, D. Wang, N. Zhao, J. Ye, Adv. Mater. 28 (2016) 6781-6803.

[10] (a) Q. Yin, J.M. Tan, C. Besson, Y.V. Geletii, D.G. Musaev, A.E. Kuznetsov, Z. Luo, K.I. Hardcastle, C.L. Hill, Science 328 (2010) 342-345;

(b) B. Rausch, M.D. Symes, G. Chisholm, L. Cronin, Science 345 (2014) 1326-1330;

(c) J. Ettedgui, Y. Diskin-Posner, L. Weiner, R. Neumann, J. Am. Chem. Soc. 133 (2011) 188-190;

(d) K. Suzuki, F. Tang, Y. Kikukawa, K. Yamaguchi, N. Mizuno, Angew. Chem. Int. Ed. 53 (2014) 5356-5360.

[11] (a) C. Streb, Dalton Trans. 41 (2012) 1651-1659;

(b) H. Lv, Y.V. Geletii, C. Zhao, J.W. Vickers, G. Zhu, Z. Luo, J. Song, T. Lian, D.G. Musaev, C.L. Hill, Chem. Soc. Rev. 41 (2012) 7572-7589;

(c) Y. Ji, L. Huang, J. Hu, C. Streb, Y.F. Song, Energy Environ. Sci. 8 (2015) 776-789;

(d) S.S. Wang, G.Y. Yang, Chem. Rev. 115 (2015) 4893-4962.

[12] (a) J. Wu, L. Liao, W. Yan, Y. Xue, Y. Sun, X. Yan, Y. Chen, Y. Xie, ChemSusChem 5 (2012) 1207-1212;

(b) Y. Zhu, M. Zhu, L. Kang, F. Yu, B. Dai, Ind. Eng. Chem. Res. 54 (2015) 2040-2047;

(c) J. Liu, S. Xie, Z. Geng, K. Huang, L. Fan, W. Zhou, L. Qiu, D. Gao, L. Ji, L. Duan, L. Lu, W. Li, S. Bai, Z. Liu, W. Chen, S. Feng, Y. Zhang, Nano Lett. 16 (2016) 6568-6575;

(d) H. Wang, C. Wang, Y. Yang, M. Zhao, Y. Wang, Catal. Sci. Technol. 7 (2017) 405-417.

[13] L. Hong, P. Win, X. Zhang, W. Chen, H.N. Miras, Y.F. Song, Chem. Eur. J. 22 (2016) 11232-11238.

[14] (a) R. Villanneau, A. Marzouk, Y. Wang, A.B. Djamaa, G. Laugel, A. Proust, F. Launay, Inorg. Chem. 52 (2013) 2958-2965;

(b) Y. Ji, J. Hu, L. Huang, W. Chen, C. Streb, Y.F. Song, Chem. Eur. J. 21 (2015) 6469-6474.

[15] J. Tian, L. Zhang, X. Fan, Y. Zhou, M. Wang, R. Cheng, M. Li, X. Kan, X. Jin, Z. Liu, Y. Gao, J. Shi, J. Mater. Chem. A4 (2016) 13814-13821.

[16] Y. Kang, Y. Yang, L.C. Yin, X. Kang, L. Wang, G. Liu, H.M. Cheng, Adv. Mater. 28 (2016) 6471-6477.

[17] B. Lin, G. Yang, B. Yang, Y. Zhao, Appl. Catal. B: Environ. 198 (2016) 276-285.

[18] T. Zhang, Q. Zhang, J. Ge, J. Goebl, M. Sun, Y. Yan, Y.H. Liu, C. Chang, J. Guo, Y. Yin, J. Phys. Chem. C 113 (2009) 3168-3175.

[19] (a) S. Aoki, T. Kurashina, Y. Kasahara, T. Nishijima, K. Nomiya, Dalton Trans. 40 (2011) 1243-1253;

(b) D. Ma, L. Liang, W. Chen, H. Liu, Y.F. Song, Adv. Funct. Mater. 23 (2013) 6100-6105.

[20] Y. Fukasawa, K. Takanabe, A. Shimojima, M. Antonietti, K. Domen, T. Okubo,
Chem. Asian J. 6 (2011) 103-109.

[21] M. Teranishi, R. Hoshino, S. Naya, H. Tada, Angew. Chem. Int. Ed. 55 (2016) 12773-12777.

[22] B. Jürgens, E. Irran, J. Senker, P. Kroll, H. Müller, W. Schnick, J. Am. Chem. Soc. 125 (2003) 10288-10300.

[23] X. Wang, K. Maeda, A. Thomas, K. Takanabe, G. Xin, J.M. Carlsson, K. Domen, M. Antonietti, Nat. Mater. 8 (2009) 76-80.

[24] Z.M. Zhang, X. Duan, S. Yao, Z. Wang, Z. Lin, Y.G. Li, L.S. Long, E.B. Wang, W. Lin, Chem. Sci. 7 (2016) 4220-4229.

[25] S.N. Talapaneni, S. Anandan, G.P. Mane, C. Anand, D.S. Dhawale, S. Varghese, A. Mano, T. Mori, A. Vinu, J. Mater. Chem. 22 (2012) 9831-9840.

[26] B. Zhu, P. Xia, W. Ho, J. Yu, Appl. Surf. Sci. 344 (2015) 188-195.

[27] W. Si, Y. Wang, Y. Peng, J. Li, Angew. Chem. Int. Ed. 54 (2015) 7954-7957.

[28] J. Gao, G. He, M. Liu, J.G. Lv, Z.Q. Sun, C.Y. Zheng, P. Jin, D.Q. Xiao, X.S. Chen, J. Alloy. Compd. 691 (2017) 504-513.

[29] Y. Wei, J. Jiao, Z. Zhao, W. Zhong, J. Li, J. Liu, G. Jiang, A. Duan, J. Mater. Chem. A 3 (2015) 11074-11085.

[30] V. Maurino, C. Minero, G. Mariella, E. Pelizzetti, Chem. Commun. (2005) 2627-2629.

[31] (a) N. Kaynan, B.A. Berke, O. Hazut, R. Yerushalmi, J. Mater. Chem. A 2 (2014) 13822-13826;

(b) H.I. Kim, O.S. Kwon, S. Kim, W. Choi, J.H. Kim, Energy Environ. Sci. 9 (2016) $1063-1073$.

[32] R. Wang, K. Pan, D. Han, J. Jiang, C. Xiang, Z. Huang, L. Zhang, X. Xiang, ChemSusChem 9 (2016) 2470-2479.

[33] D.C. Duncan, R.C. Chambers, E. Hecht, C.L. Hill, J. Am. Chem. Soc. 117 (1995) 681-691.

[34] (a) M. Kim, I.A. Weinstock, Y.V. Geletii, C.L. Hill, ACS Catal. 5 (2015) 7048-7054;

(b) M. Zhang, J. Hao, A. Neyman, Y. Wang, I.A. Weinstock, Inorg. Chem. 56 (2017) 2400-2408.

[35] Y. Kofuji, S. Ohkita, Y. Shiraishi, H. Sakamoto, S. Tanaka, S. Ichikawa, T. Hirai, ACS Catal. 6 (2016) 7021-7029.

[36] H. Sheng, H. Ji, W. Ma, C. Chen, J. Zhao, Angew. Chem. Int. Ed. 52 (2013) 9686-9690.

[37] Y. Liu, H. Liu, C. Wang, S.X. Hou, N. Yang, Environ. Sci. Technol. 47 (2013) 13889-13895.

[38] C. Liu, L. Jing, L. He, Y. Luan, C. Li, Chem. Comm, 50 (2014) 1999-2001.

[39] C. Zhao, H. Luo, F. Chen, P. Zhang, L. Yi, K. You, Energy Environ. Sci. 7 (2014) 1700-1707.

[40] R.L. Spray, K.J. McDonald, K.S. Choi, J. Phys. Chem. C 115 (2011) 3497-3506.

[41] (a) B. Li, Y. Zhao, S. Zhang, W. Gao, M. Wei, ACS Appl. Mater. Interfaces 5 (2013) 10233-10239;

(b) J. Liu, Y. Liu, N. Liu, Y. Han, X. Zhang, H. Huang, Y. Lifshitz, S.T. Lee, J. Zhong, Z. Kang, Science 347 (2015) 970-974.

[42] J. Chen, P. Wagner, L. Tong, G.G. Wallace, D.L. Officer, G.F. Sweigers, Angew. Chem. Int. Ed. 51 (2012) 1907-1910.

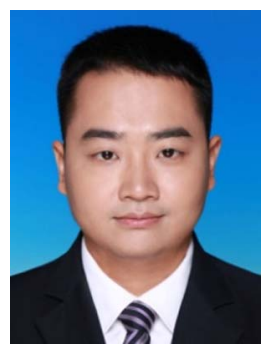

Shen Zhao obtained his Ph.D. degree in school of science at Beijing University of Chemical and Technology in 2014. Now he is an Assistant Professor in Key Laboratory of Drinking Water Science and Technology at Research Center for Eco-Environmental Sciences of Chinese Academy of Sciences. His research interests focus on materials chemistry and photocatalysis.

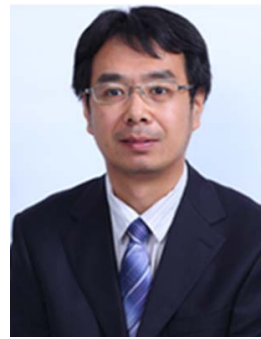

Xu Zhao obtained his Ph.D. degree in Department of environmental science and technology at Dalian University of Technology in 2004. Now he is a Professor in Key Laboratory of Drinking Water Science and Technology at Research Center for Eco-Environmental Sciences of Chinese Academy of Sciences and University of Chinese Academy of Sciences. His research interest involves electrochemistry, photocatalysis and water treatment. 


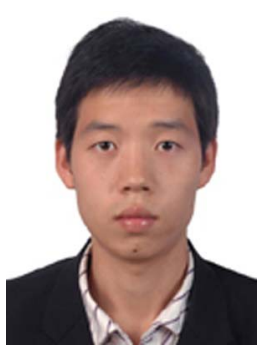

Hui Zhang obtained his Ph.D. degree in Department of environmental science and technology at Dalian University of Technology in 2011. Now he is an Associate Professor in State Key Laboratory of Environmental Chemistry and Ecotoxicology at Research Center for Eco-Environmental Sciences of Chinese Academy of Sciences. His research interests focus on materials chemistry and photocatalysis.

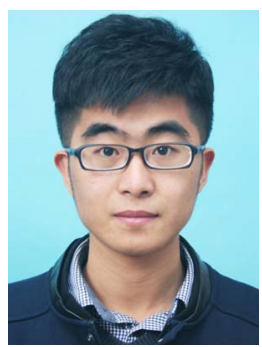

Jiang $\mathbf{~ L i ~ i s ~ a ~ j o i n t ~ t r a i n i n g ~ M a s t e r ~ c a n d i d a t e ~ i n ~ S c h o o l ~ o f ~}$ Light Industry and Chemical Engineering at Dalian Polytechnic University and Key Laboratory of Drinking Water Science and Technology at Research Center for EcoEnvironmental Sciences of Chinese Academy of Sciences. His research interests focus on photocatalysis.

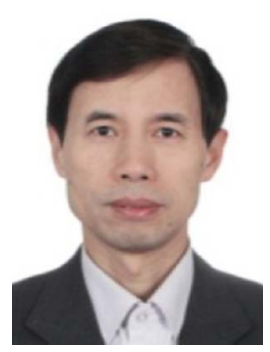

Yongfa Zhu obtained his Ph.D. degree in Chemistry Department at Tsinghua University in 1995 . Now he is a Professor in Chemistry Department at Tsinghua University. His research interests focus on surface chemistry, materials chemistry and photocatalysis. 